\title{
Sobre la santidad de Mónica, la madre de san Agustín
}

\author{
Prof. Dr. Pío de Luis Vizcaíno \\ Estudio Teológico Agustiniano de Valladolid
}

Recibido: 16 junio 2021

Aceptado: 16 septiembre 2021

RESUmen: Los hagiógrafos de santa Mónica la presentan como una gran santa; biógrafos y otros estudiosos de san Agustín ofrecen de ella una imagen menos edificante. ¿A quiénes da la razón san Agustín, a quien debemos cuanto conocemos de ella? El presente estudio examina las Confesiones del santo -la fuente más abundante de información-desde esa perspectiva. La primera parte se ocupa de los libros 1-8; la segunda, del libro 9. En la primera se muestra cómo el hijo combina, desde el punto de vista moral-espiritual, alabanzas y críticas a la madre por el papel que desempeñó mientras lo acompañaba en su doble recorrido: hacia una vida cristiana coherente dentro de la Iglesia católica y hacia el éxito en la sociedad del imperio; en la segunda se muestra cómo Agustín elimina esa dicotomía, ofreciendo una imagen unificada de Mónica, la que se impuso entre los fieles. En medio hubo una conversión de la madre, equiparable en cierta medida a la del hijo.

Palabras clave: Mónica, Confesiones, éxito social, fe y moral católicas, conversión, gozo, pecado, vida en Dios, santidad.

ABSTRACT: The hagiographers of Saint Monica present her as a great saint; Biographers and other scholars of Saint Augustine offer a less edifying image 
of her. To whom does Saint Augustine agree, to whom we owe how much we know about it? This study examines the Confessions of the Saint - the most abundant source of information - from that perspective. The first part deals with books 1-8; the second, from book 9. The first shows how the son combines, from the moral-spiritual point of view, praise and criticism of the mother for the role she played while accompanying him on his double journey: towards a coherent Christian life within the Catholic Church and towards success in the society of the empire; the second shows how Agustín eliminates this dichotomy, offering a unified image of Monica, the one that prevailed among the faithful. In the midst of it there was a conversion of the mother, to some extent comparable to that of the son.

Keywords: Monica, Confessions, social success, Catholic faith and morals, conversion, joy, sin, life in God, holiness.

\section{Preámbulo}

Mónica, la madre de Agustín, figura desde siglos en el catálogo de santos de la Iglesia católica ${ }^{1}$. Pero, al parecer, los autores de la reforma litúrgica ordenada por el Concilio, que supuso también modificaciones en el Calendario universal de las fiestas de los santos, estuvieron a punto de sacarla de él. Según se cuenta, así lo había decidido la Comisión nombrada por la Santa Sede para el caso. Solo que, cuando lo supo san Pablo VI, ordenó que se la restituyera, aunque cambiando la fecha de su memoria: en vez del 4 de mayo anterior, pasaría a celebrarse como memoria obligatoria para toda la Iglesia el 27 de agosto, el día previo a la de su hijo Agustín.

${ }^{1}$ El culto de santa Mónica en la Iglesia universal comenzó en el 1430 con motivo del traslado de sus restos de Ostia Antica a Roma; no obstante, ya a comienzos del s. V florecía en torno a su tumba en Ostia Antica -entonces puerto de Roma- una cierta veneración, de la que es prueba el epitafio escrito por el excónsul Anicio Auquenio Basso y grabado en una lápida. El traslado tuvo lugar el 9 de abril del 1430 a la iglesia de San Trifón y 25 años más tarde a la de San Agustín, ambas en Roma. Cf. A. TrAPÈ, «Monica», en Bibliotheca Sanctorum IX (Roma 1967) 548-562, y M. CHIABÒ - M. GARGANO - R. RonZANI (ed.), Santa Monica nell'Urbe dalla Tarda Antichità al Rinascimento. Storia, Agiografia, Arte. Atti del Convegno Ostia Antica-Roma, 29-30 settembre 2010 (Roma 2011). Recientemente, G. Falbo ha suscitado dudas sobre la autenticidad de los restos de santa Mónica conservados en la iglesia de San Agustín (cf. Santa Monica [San Paolo, Cisinello Balsamo 2003], p. 141-142). Al final de estas páginas volveremos sobre el culto de la santa. 
En el caso de ser verídico lo que se cuenta, cabe preguntarse a qué se debía la reticencia a mantener a Mónica en el calendario universal de la Iglesia. ¿Es que no hay en esta época mujeres que sufren el extravío religioso y moral de sus maridos e hijos, que pueden acudir a ella buscando consuelo y ayuda? La respuesta ya se sabe: las ha habido y seguirá habiéndolas siempre, y en la actualidad quizá más que nunca. ¿O es que Mónica no da la talla como santa para merecer ser propuesta como modelo de imitación para las esposas y madres cristianas? La pregunta está justificada porque, junto a numerosas biografías -en la práctica hagiografíasque la ensalzan como una gran santa ${ }^{2}$, no faltan biografías o estudios sobre Agustín más que sobre Mónica- que la presentan con cualidades que se avienen mal con la idea de santidad comúnmente aceptada. Según algunos autores, era una mujer sarcástica, dominadora, inexorable, tirana, posesiva, fría, vengativa, implacable, cruel, etc. ${ }^{3}$.

Tiene, pues, sentido examinar desde esa perspectiva las fuentes relativas a Mónica. Una observación se hace necesaria: la santidad es un hecho teológico y no es competencia del estudioso expedir a nadie certificados o títulos oficiales al respecto. Pero, aunque se trata de una realidad fundamentalmente interior, la santidad va asociada a una fenomenología específica, a unos parámetros de conducta moral y espiritual, perceptibles a los ojos, que se han ido definiendo a lo largo de siglos de tradición cristiana. A partir de ahí no parece ningún contrasentido hablar o juzgar de la santidad o no santidad de determinada persona, aun fuera de los cauces canónicos establecidos con vistas a declararla.

Las fuentes que nos aportan información sobre Mónica son todas agustinianas. De hecho, de Mónica solo sabemos lo que su hijo Agustín nos dice, siendo, además, muy pocas las palabras explícitas de ella que nos

${ }^{2}$ Algunas de ellas irán apareciendo a lo largo del estudio.

${ }^{3}$ Estos son solo algunos de los adjetivos utilizados para describir a Mónica por autores como P. Brown (cf. Augustine of Hippo. A Biography, A New Edition with an Epilogue, Berkley-Los Ángeles 2000), G. Schwarz (cf. Che cosa ha veranmente detto sant'Agostino, Roma 1971), B. Altaner (cf. Patrologie. Leben, Schriften und Lehre der Kirchenväter. Durchgesehen und ergänzt von A. Stuiber. Friburgo en Brisgovia 1978) y G. Lettieri (cf. Agostino d'Ippona. Invito ala lettura, Milano 1999), que tomamos de G. Saginario (Monnica mia madre, 288. Cf. el apartado: «Voces de contraste», p. 266-290). La autora los rebate aunque, a nuestro parecer, no con el método adecuado. 
transmitió ${ }^{4}$. Él seleccionó los datos que juzgó oportunos, los dispuso como mejor le pareció y los enjuició según sus episcopales criterios. Esas fuentes se reducen a los tres diálogos de Casiciaco-Contra los escépticos, La vida feliz y El orden- y, sobre todo, las Confesiones; a ellas hay que añadir otros cuatro textos muy breves y puntuales: ep. $36,32{ }^{5}$ y 54,3 , cura. mort. $16 ; c$. Iul. imp. 1,68 , y perseu. $53^{6}$. Lo lógico sería rastrearlas todas; pero eso no quita que, a nivel de investigación, centremos nuestro estudio en las Confesiones, la fuente principal. No solo por ser la que ofrece mayor información, sino por algunas características propias: el haber sido escritas unos diez años después de la muerte de Mónica, es decir, con tiempo para repensar los hechos, y por la gran carga teológica ${ }^{7}$ que de ahí se deriva.

Importante es tener en cuenta que los datos sobre la santidad o no santidad de Mónica se encuentran casi exclusivamente en el ámbito de sus relaciones con el hijo Agustín, que este privilegia de forma absoluta en su relato. De hecho, deja en la penumbra las relaciones de la madre y

${ }^{4}$ Solo raramente indica Agustín estar refiriendo palabras textuales de su madre: a propósito del sueño en que se le anuncia la futura vuelta a la fe del hijo (conf. 3,19-20), al término del «éxtasis de Ostia» (ib., 9,26) y durante su última enfermedad (9,26-30) (cf. E. LAMIRANDE, «Quand Monique, la mère d'Augustin, prend la parole», en A. ZuMKelleR (ed.), Signum Pietatis, p. 3-19:12-15). Más en concreto, Agustín nunca pone en boca de Mónica una autocensura; toda censura de madre sale de la pluma del hijo (P. RIGBY, «Was Augustine a narcissist?», 66). El libro de L. TANCREDI, Io, Monica. Le confessioni della madre di Agostino (Città Nuova, Roma 2006) no responde, como era de suponer, al título.

${ }^{5}$ La obra agustiniana solo la indicamos cuando no se trata de las Confesiones. La falta de este dato indica que la referencia remite a esta obra. En las referencias prescindimos del capítulo, limitándonos a señalar el libro (cuando existe) y el parágrafo.

${ }^{6}$ A lo más, se podría añadir el epitafio que su autor, Anicio Auquenio Basso mandó poner sobre su tumba en el 408, es decir, unos 20 años después de la muerte de Mónica-... Un fragmento de la lápida que lo contenía fue descubierto en el lugar en 1945 cerca de la tumba de la mártir santa Áurea, en cuya iglesia se conserva actualmente. Su texto reza así: «Aquí depositó sus cenizas la madre santísima de un hijo. Nuevo brillo para tu mérito, Agustín, que, como sacerdote, defiendes los derechos de la paz celeste y enseñas el recto obrar a las gentes a ti confiadas. Madre de virtudes, más dichosa por tal hijo: a ambos os corona una gloria mayor que la alabanza de vuestras gestas».

${ }^{7}$ Sobre la influencia que en la presentación de los hechos por parte de Agustín han tenido sus intenciones y personales convicciones en el momento de escribir las Confesiones, y en cierta medida su pasado, cf. M. More O'Ferrall, « Monica, the Mother of Augustine. A Reconsideration»: Recherches augustiniennes 10 (1975) 23-43: 26-27. 
suyas con sus otros hijos y hermanos ${ }^{8}$, y de la relación de ella con el entorno familiar y social más amplio afirma explícitamente que se limita a presentar los dones que Dios le hizo, es decir, solo sus aspectos positivos ${ }^{9}$.

Las Confesiones son, pues, la fuente en la que vamos a beber. Pero es preciso distinguir entre los ocho primeros libros y el noveno ${ }^{10}$, los únicos que aportan información sobre Mónica. Tanto aquellos como este tienen importancia, pero diferenciada. La lectura de los primeros deja ver que en Mónica hay también tinieblas morales y espirituales; la lectura del úl-

${ }^{8}$ Hay certeza de que del matrimonio de Patricio y Mónica nacieron tres hijos, dos varones -Agustín y Navigio- y una mujer, cuyo nombre se ignora. Cabe que tuvieran más, pero es solo una posibilidad. La información de Agustín sobre sus hermanos se reduce a un comentario, a primera vista un tanto despectivo, sobre su otro hijo, seguramente Navigio, (conf. 9,27$)$ y a la afirmación genérica, referida al conjunto de los hijos, de que los había nutrido y parido tantas veces cuantas los veía apartarse de Dios (conf. 9,22). Esta afirmación justifica que formulemos la pregunta de si también sus otros hijos tuvieron una historia espiritualmente agitada, pregunta para la que no hay respuesta. Por otra parte, la razón que se suele dar de ese silencio sobre sus otros hermanos y resto de familia es que no tuvieron ningún influjo en su experiencia de conversión (cf. L. SEELBACH, «"Wie sollte ich selbst da nicht mit Freuden dein Schüler werden wollen?” Augustin über Monnicas Weg zu Gott»: Augustiniana 55 [2005] 297-319: 307).

${ }^{9}$ Sobre ello volveremos dentro de poco.

${ }^{10}$ P. Courcelle sugiere la existencia de una breve biografía de Mónica anterior a las Confesiones, una parte de la cual la habría incorporado san Agustín al libro noveno (Recherches sur les Confessions de saint Augustin [Paris 1968²], p. 36, n.7). Por otra parte, C. Alonso del Real opina que los capítulos del 8 al 13 (\$§ 17-37) constituyen un elogio fúnebre de Mónica, una laudatio Monnichae («Monnichae laudatio», en I. P. AugustiniAnum (ed.), Le Confessioni di Agostino (402-2002): Bilancio e prospettive. XXXI Incontro di studiosi dell'antichità cristiana, Roma, 2-4 maggio 2002 [Studia Ephemeridis Augustinianum 85, Roma 2003], p. 233244). Efectivamente, en esos capítulos encontramos un elogio de Mónica, pero no resulta fácil aceptar que se trate de un elogio fúnebre como unidad literaria. Solo algunas preguntas de las muchas que tal opinión suscita: ¿cabe pensar que, en ese caso, Agustín pasase por alto las relaciones de su madre con él durante muchos años, siendo así que su retorno a la fe de la Iglesia podría considerarse como el primer y más justificado motivo para alabarla? ¿Es posible que hasta las puertas del «éxtasis» de Ostia no encontrase nada que alabar en su relación personal con ella? ¿O pasa por alto lo dicho en los ocho primeros libros porque las críticas a la madre que en ellos aparecen desdorarían el elogio? Además, como la autora misma reconoce, es difícil encajar en ese marco el último capítulo (\$§ 34-36) porque en él rompe el esquema narrativo en pasado y pide perdón a Dios por su madre (p. 241). Ni siquiera la alternativa de pensar no tanto en una laudatio Monnicae, sino en una laudatio Dei in Monnica, da una respuesta adecuada a las preguntas formuladas. 
timo solo ofrece luz. El libro noveno se puede comparar con la llegada a una meta; los ocho primeros con el trayecto que hay de recorrer para llegar a ella, trayecto en el que surgen problemas a los que se puede dar solución adecuada o inadecuada.

En el trayecto representado por los ocho primeros libros se pueden contemplar formalmente dos recorridos simultáneos e inseparables de Agustín: el recorrido hacia el éxito social y el recorrido hacia la fe católica, ambos hechos bajo la tutela, aceptada por él o no, de la madre Mónica. El primero lo inició, ya con éxito, siendo aún niño; siguió por él en su «adolescencia»y se le cegó apenas entrado en la «juventud»; el segundo -el de la fe católica- lo inició en la infancia, lo abandonó en la «adolescencia» y lo recuperó en la «juventud» ${ }^{11}$. El primer recorrido, lineal, no concluyó en la meta soñada; el segundo, sí, a pesar de sus tortuosidades. El libro noveno, en cambio, refiere sobre la etapa de la vida de Agustín en la que, habiendo renunciado al éxito social, disfruta y goza en el destino religioso finalmente alcanzado. Insistimos en el hecho de que Mónica acompaña ambos recorridos de su hijo Agustín, no como simple espectadora, sino con una intervención activa, impulsando opciones unas veces acertadas y otras equivocadas según los criterios de Agustín, los que aquí nos interesan ${ }^{12}$. Opciones y motivaciones que él juzga positiva o negativamente.

En el libro noveno, Agustín se presenta a sí mismo cargado con la alforja de su vida pero ahora puesta atrás la bolsa con sus antiguas apetencias ${ }^{13}$ y delante la bolsa con Cristo $(9,1)$. A su madre la presenta de modo similar: en la bolsa de atrás lleva virtudes y vicios y en la de delante solo virtudes. La razón última es la misma: el cierre del libro octavo contiene tanto la conversión de Agustín como la de su madre Mónica; idénticas en

${ }^{11}$ El entrecomillar las etapas de la adolescencia y de la juventud, se debe a que en san Agustín estas etapas de la vida humana tienen unas equivalencias cronológicas distintas las que tienen los mismos términos en español. En el mundo latino, se era adolescente desde los 17 a los 30 años, y joven desde los 30 a los 45 .

${ }^{12}$ Es frecuente entre los biógrafos justificar, partiendo de criterios o praxis actuales, decisiones de Mónica como el retardar el bautismo cuando el niño lo pidió o no procurarle el matrimonio al advertir la fuerza de sus impulsos sexuales. Lo que nos interesa es únicamente el juicio de Agustín.

${ }^{13}$ Aunque llevando aún alguna consigo: «jadeando de orgullo académico» (Conf. 9,7). 
cuanto conversión, aunque distintas, al menos parcialmente, en sus puntos de partida y de llegada.

Los hagiógrafos, ávidos siempre de virtudes con que adornar a sus santos, apuran el libro noveno para que no se les escape ninguna. Pero no advierten que en sus capítulos octavo y noveno ( $\$ 17-22$ ) Agustín contempla a su madre en relación con su otro entorno inmediato -sus padres, la servidumbre de su casa, su marido, su suegra, sus vecinas y -con suma brevedad-sus otros hijos e «hijos»- pero no en la relación concreta con Agustín, respecto de la cual ha señalado en los libros anteriores los aciertos y equivocaciones aludidos. Por otra parte, no toman suficientemente en serio las palabras, referentes a su madre, con que Agustín mismo abre la sección: «No hablaré de cualidades propias, sino de las que tú -Diosle regalaste» (conf. 9,17). Claramente opta por una «discriminación positiva» de los datos, excluyendo los negativos, que nunca cabe considerar don de Dios. Ni la mención de la afición al vino de Mónica aún niña se sale de ese principio pues le sirve para mostrar que fue la medicina de Dios la que la curó de esa enfermedad (conf. 9.18) ${ }^{14}$.

El hagiógrafo puede estar tentado de considerar este libro noveno -recurriendo a la terminología propia de los procesos de canonizacióncomo la positio o documento que pondera las virtudes heroicas del candidato a la canonización que han de conducirlo a ella y aparca cuanto puede impedirla, a veces olvidando afirmaciones anteriores. Por ejemplo, la madre Mónica que en el puerto de Cartago había acusado al hijo de mentiroso y cruel (conf. 5,15), en el libro noveno sostiene que siempre había sido para ella un buen (pius) hijo ${ }^{15}$. Solo que, aunque esos capítulos se pueden considerar como un complemento que sirve a la causa, el razonamiento principal de Agustín sigue otro camino. Varios datos nos llevan, pues, a relativizar, desde la perspectiva que nos ocupa, cuanto afirma Agustín de su madre en esa parte del libro noveno: los datos que refiere

${ }^{14}$ Hay autores que establecen una comparación entre el «robo» de vino de la niña Mónica y el robo de las peras de Agustín adolescente $(2,9)$ para mostrar el contraste entre el proceder de una y otro (cf. K. Power, Veiled Desire. Augustine on Women [Continuum, Nueva York, 1996], p. 73: L. SEELBACH, «Monnika», p. 70).

15 Ciertamente, san Agustín matiza al añadir: «en cuanto que nunca la había herido con su palabra» $(9,30)$. Pero esa precisión deja entender que en otros aspectos no había sido tan pius, $\tan$ buen hijo. 
no están ubicados en el lugar que cronológicamente les correspondería; refiere solo dones otorgados por Dios a su madre; pasa por alto la relación conflictiva con el hijo; la información que ofrecen los libros anteriores, aunque no es opuesta, deja otra imagen de Mónica. No se trata de negar la veracidad de lo allí afirmado, sino de descifrar el significado que tiene su específica ubicación en la trama del relato.

Es cierto que los hagiógrafos beben también en los primeros ocho libros, pero con frecuencia lo hacen de forma parcial y acomodadiza; su lectura suele ser selectiva, sin que por ello pretendamos atribuirles una acción conscientemente manipuladora. En realidad, no advierten la lógica que, desde el punto de vista de la moralidad y espiritualidad de Mónica, gobierna esos libros. No aciertan a acompañarla en los dos recorridos simultáneos, correspondientes al doble objetivo que ella tenía en relación con su hijo Agustín: que alcanzase el éxito social y que se mantuviese dentro de la fe y moral católicas. Deslumbrados por la luz que proyecta su empeño en conseguir este segundo objetivo, no perciben las oscuridades que aparecen en el primero y, aunque menores, también en el segundo. Tanto se detienen en los parajes religiosamente cálidos del segundo recorrido, que pasan de largo de los parajes moralmente fríos del primero y tibios del segundo. Agustín se muestra más objetivo que ellos, pues, reconociendo el empeño de su madre en conseguir ambos objetivos, le hace una dura crítica, que no hay que desestimar por su importancia para lo que nos ocupa: la santidad de Mónica. De hecho -repetimos-, son precisamente los juicios, positivos o negativos, de san Agustín los que interesan. Nuestra valoración no pretende tener otro fundamento que el juicio emitido por él sobre las acciones, palabras y pensamientos de Mónica. Existe, por supuesto, la posibilidad de error en la interpretación de ese juicio, pero es un riesgo que debe asumir todo intérprete de un texto ajeno.

Antes de entrar directamente en el examen de los textos, es preciso plantearse otro problema que presentamos en estos términos: ¿Merece credibilidad un hijo cuando habla de su madre? Y, más en concreto, ¿es fiable Agustín en lo que nos refiere acerca de Mónica? La respuesta, en principio, solo puede ser positiva, recurriendo, no a su amor a la verdad, como suelen hacer los hagiógrafos, sino al llamado «criterio de las averías», utilizado en la crítica histórica. La lógica de tal criterio la expresa perfectamente el dicho español: «nadie tira piedras sobre el propio tejado». Dejando de lado la imagen, lo formulamos así: si una persona sen- 
sata e inteligente afirma algo que se opone a la tesis que defiende, parece lógico aceptar su afirmación como verídica. Ya en concreto: si Agustín es capaz de manifestarse crítico con su madre a la que, por otra parte, tan unido se muestra, merece credibilidad, mientras no se demuestre positivamente lo contrario.

\section{Análisis de Confesiones 1-8}

Para el examen de los ocho primeros libros de las Confesiones tomamos como pauta los dos recorridos señalados.

\section{a) Mónica acompaña al hijo en su recorrido hacia la fe católica}

La presentación de este recorrido será breve por ser demasiado conocido. Comienza ya en su infancia. La profunda piedad -entiéndase aquí amor materno- de Mónica se manifiesta en que, nada más nacer Agustín, procuró que fuese acogido en la Iglesia en condición de catecúmeno $(1,17)$; en que el niño mamó con la leche materna la adhesión Cristo $(4,8)^{16}$; en que procuró que valorase más la paternidad espiritual de Dios que la biológica de Patricio, su padre (conf. 1,17). Gracias a la obra de la madre, Agustín creyó siempre en Dios, en su providencia, en el juicio final, en la vida eterna $(6,8.26)$. Sin la educación cristiana recibida de ella, difícilmente el niño ${ }^{17}$ habría pedido el bautismo con ocasión de una enfer-

${ }^{16}$ Lo que permite deducir que también Mónica amamantó a su hijo $(3,8)$, algo que no siempre sucedía. Significativamente, con referencia a la propia lactancia, san Agustín no habla específicamente de leche materna, sino de leche humana (1,7.11). El recurso a nodrizas era frecuente. El hecho tiene su significado habida cuenta que, según opinión de los moralistas romanos, la moralidad y la sensibilidad religiosa se podía trasmitir con la leche del pecho y, en consecuencia, dar el pecho aparece como un deber materno con profundo significado espiritual (cf. K. Power, Veiled Desire, p. 78).

${ }^{17}$ ¿A qué edad? La referencia a su niñez nos coloca entre los 7 y los 16, según el cómputo de entonces. A. Trapè afirma, sin dar razón alguna, que a los 16 años (Vida de Santa Mónica [Ediciones Angular, Bogotá 1985] p. 20. Traducción al español de la obra Sant'Agostino. Mia madre [Piccola Biblioteca agostiniana, Roma 1978]). Un poco tarde parece, si se tiene en cuenta, primero, que Mónica pensaba en las olas de tentaciones que le sobrevendrían una vez pasada la niñez (post pueritiam) y, luego, que Agustín afirma de sí mismo que, a sus 15 años cumplidos (sexto et decimo anno), ya vio elevarse sobre su cabeza las zarzas de sus lascivias, y que Mónica fue, al menos, advertida por Patricio $(2,6)$. Los siete u 
medad $(1,17){ }^{18}$. Conseguido el objetivo de que la semilla de la fe germinara en el hijo, se centró en otro: en que respetase la moral cristiana, especialmente en el ámbito de la castidad. Como ejemplo de ello, Agustín aduce la viva recomendación que le hizo de que no fornicase y, sobre todo, de que no cometiese adulterio $(2,7)^{19}$.

Es frecuente que los hagiógrafos pongan al servicio de su causa las muchas lágrimas derramadas $(3,19.21 ; 5,13.15 .17 ; 6,1){ }^{20}$ y las continuas súplicas elevadas a Dios $(3,20 ; 5,15.17 ; 6,1)$ por el hijo cuando este pasó a formar parte de la secta maniquea; el no admitirlo en su casa por ser maniqueo $(3,19 ;$ acad. 2,3$)$-«indómita fe de una madre»- ${ }^{21}$; el recurso -por cierto sin éxito- a todo obispo que encontraba para que hablase con su hijo por si lograba quitarle las telarañas aposentadas en su corazón y del que recibió la conocida respuesta: «no puede perecer el hijo que ha costado tantas lágrimas» $(3,21)$; su empeño en que el hijo renunciase a toda costa al viaje a Italia o, de no ser así, en acompañarlo (5,15); el que no tardando mucho afrontase el riesgo de seguirle por mar y tierra a Milán (6,1); la asistencia diaria a la Eucaristía $(5,17 ; 9,36)$; la adhesión plena a la persona y órdenes del obispo Ambrosio (6,2); el incondicional apoyo que le prestó en su enfrentamiento con la emperatriz Justina $(9,15)$; que se moviese con habilidad para concertar un matrimonio con una joven que, al ser católica $(6,23)$, facilitara que el hijo recibiera el bautismo; por último, la alegría que manifestó cuando Agustín y el amigo Alipio le comunicaron su vuelta a la fe católica $(8,30)$.

ocho años que propone G. Falbo (Santa Mónica, p. 49) pueden acercarse más a la realidad, porque dejan un margen de tiempo asumible para la evolución religiosa de Mónica y Patricio, de que hablaremos más adelante.

${ }^{18}$ Con todo, el dato hay que ponerlo en el haber del niño, que fue quien lo solicitó, no en el de la madre que solo entonces decidió intervenir y que, además, renunció a que se le administrase el sacramento tan pronto como el niño salió del peligro. La pregunta surge: si tan preocupada estaba por la salvación del hijo, ¿por qué no salió de ella la decisión de procurar que se le administrase?

${ }^{19}$ En ese período emergen fuertes corrientes subterráneas de tensión emocional entre la madre y el hijo (cf. K. Power, Veiled desire, p.78).

${ }^{20}$ Sobre el significado de las lágrimas de Mónica y los diversos contextos en que las derrama, cf. M. DULAEY, «Scatentes lacrimis confessionum libros. Les larmes dans les Confessions», en I. P. Augustinianum (ed.), Le Confessioni di Agostino (402-2002), p. 215-232.

${ }^{21}$ G. Vigini, Sant'Agostino. L'avventura della grazia e della carità. San Paolo, Milano 2006, p.35. 
Ninguno de estos detalles, tomados todos ellos de las Confesiones, ponemos en duda. Pero algunos requieren un comentario y otros suscitan algunas preguntas, además de que han de ser completados con otros datos, presentes también en la misma obra. Por ejemplo, resulta extraño que Agustín no aprendiera a orar en casa, sino en la escuela, como parece poder deducirse de este texto: «Dimos por fortuna con hombres que te invocaban y de ellos aprendimos a sentirte como un ser grande que, aun no apareciendo a los sentidos, podía escucharnos y venir en nuestra ayuda. De ahí que, siendo aún niño, comencé a invocarte como a mi refugio y amparo y en su invocación rompí los nudos de mi lengua...» $(1,14)$. ¿Cabe pensar que su madre no le había enseñado a rezar? ${ }^{22}$.

Resulta asimismo extraño que Agustín no advirtiera que lo que él -ya a las puertas de su conversión- creía acerca de Cristo era contrario a la fe católica, pues pensaba lo mismo que el hereje Fotino $(7,25)$. ¿No ha escrito él mismo que, «siendo aún niño, había oído hablar de la vida eterna prometida por la humildad de Dios nuestro Señor, que descendió hasta nuestra soberbia» $(1,17)$, con referencia clara a la encarnación, negada por Fotino? ¿Cabe concluir que la buena voluntad de la madre no iba acompañada de una correcta formación cristiana? ${ }^{23}$.

Volvamos atrás a los hechos y actitudes tan altamente ponderados. El primero de ellos, la petición del bautismo que hizo Agustín aún niño.

\footnotetext{
${ }^{22}$ Agustín no dice explícitamente que fuese en la escuela, aunque el contexto permite deducirlo, puesto que está hablando de castigos que en ella recibía y que en sus primeras oraciones pedía verse libre de ellos. En ese sentido cabe interpretar el que habla de «hombres», salvo que aquí tenga el significado genérico de persona humana. Si hubiera sido el caso, ¿qué le impedía atribuir ese «mérito» a su madre? ¿Acaso porque no cuadraba con la crítica que acababa de hacerle? (cf. más adelante, p. 20). ¿O hay que entender en sentido restrictivo la afirmación de que entonces comenzó a invocar a Dios como su refugio y amparo, lo cual no impediría que ya antes se dirigiese a Dios en otros contestos y con otros objetivos? Pero, en este caso, sigue resultando extraño que fuesen esos «hombres» quienes le enseñasen que «Dios es un ser grande que podía... escucharnos y venir en nuestra ayuda» $(1,14)$.

${ }^{23} \mathrm{Al}$ respecto escribe B. Dobell: «Podemos preguntarnos cómo Agustín pudo haber llegado a confundir catolicismo y fotinianismo. ¿No había sido educado por una madre cristiana? ¿No había conocido ya desde la niñez que Cristo había descendido al nivel de la humanidad pecadora? $(1,17)$ ? El hecho constatado es que Agustín estaba confundido en cuanto a la cristología y cayó en la herejía fotiniana (conf. 7,25) (Augustine's Intellectual Conversion. The Journey from Platonism to Christianity [Cambrigge University Press, 2009], p. 69).
} 
Aunque afirma haberlo pedido él a su madre biológica y a la madre de todos, la Iglesia ${ }^{24}$, la valoración no la centra en esta, sino en aquella. Primero alaba su solicitud para que fuera iniciado con el sacramento de la salvación; luego critica que, tras recuperar él la salud, difiriese su recepción, dando ella por hecho que inevitablemente iba a mancharse en el futuro, con culpa mayor. Mónica manifestaba así una falta de fe en el poder de la gracia del sacramento ${ }^{25}$ y una actitud casi fatalista, como si necesariamente hubiera de suceder lo que ciertamente podía suceder ${ }^{26}$. El hijo interpreta esa dilación como un soltarle las riendas para pecar, es decir, para enfermar más. Tan inconcebible le resulta que pide a Dios que, si lo tiene a bien, le explique las razones del actuar de su madre. Al final, sin embargo, quiere atenuar la crítica, señalando que ella conocía bien los peligros morales que le esperaban, una vez superada la niñez, y no quiso que la imagen de Dios presente en el hijo acabara seriamente dañada $(1,17-$ 18).

La afirmación de que Mónica procuró que el hijo valorase más la paternidad espiritual de Dios que la biológica de Patricio, su padre (conf. 1,17), plantea asimismo algún interrogante. En efecto, si Mónica tenía en tanto la paternidad espiritual de Dios respecto de su hijo, y si esa paternidad se obtiene mediante la recepción del bautismo, ¿por qué tan pronto como pudo postergó su recepción por parte del niño, habiéndola solicitado él? ¿O le bastaba con una vivencia psicológica de filiación sin su base real y objetiva? Y, con relación a Agustín, si está buscando motivos para «salvar» a su madre tras ese tropiezo, no parece que haya acertado.

${ }^{24}$ Para mostrar que Mónica es presentada como figura de la Iglesia madre, J. Sehorn señala que Mónica estaría aquí «en lugar de la Iglesia» (in loco ecclesiae) («Monica as Synecdoche for the Pilgrin Churh in the Confessiones»: Augustinian Studies 46/2 (2015) 225-248: 232). Pero difícilmente puede sostenerse dado que menciona explícitamente a «la madre de mi carne» y a «la madre de todos nosotros, tu Iglesia». La misma distinción está implícita en el relato previo de la inscripción del niño Agustín como catecúmeno.

${ }^{25}$ Como alternativa a la opción tomada por Mónica en ese caso concreto, Agustín afirma que habría sido mejor para él, haber sido curado de inmediato y que luego él y los suyos se esforzasen para que la salvación recibida quedase asegurada bajo la protección de Dios $(2,18)$. Por tanto, Agustín parece estar diciendo que si Mónica no tomó este camino «mejor» para salvaguardar la salud moral del hijo, fue porque no lo consideraba eficaz.

${ }^{26}$ Cf. R. J. O'Connell, Images of conversion in St. Augustine's Confessions (Fordham University Press, Nueva York 1996), p. 20. 
La pregunta que ahora formulamos -de interés puramente históricoes otra: ¿estaba Mónica bautizada ya entonces?27. La duda la suscitan estas palabras: «Entonces ya creía yo y ella -Mónica- y toda la casa, a excepción de mi padre» $(1,17)$. El hecho de haber pedido el bautismo cuando aún era niño, ofrecía a Agustín un contexto óptimo para señalar la diferente condición personal respecto de la Iglesia de los miembros de su familia y, en concreto, para hacer saber que Mónica ya estaba bautizada, si tal fuera el caso. Igual que señala que su padre aún no llegaba al mínimo -la fe-, podía haber señalado que su madre excedía ese mínimo -si hubiera sellado su fe con el bautismo-. Y, sin embargo, también a ella la incluye dentro de ese mínimo de que participaba la casa entera, con la excepción indicada. Al equiparar la condición de su madre a la propia, si él no estaba bautizado parece lógico concluir que tampoco su madre. Lo más que parece poder deducirse del texto es que Mónica tenía máximo interés en la salvación de su hijo y que conocía que esa salvación pasaba por recibir el bautismo que perdonaba todo pecado. Y hasta puede entenderse que, una vez pasado el peligro para el hijo, la madre renunciase al bautismo; en efecto, en el supuesto indicado, llevar a bautizar al hijo, sin bautizarse ella también, ¿no mostraría una notable incoherencia, aun reconociendo que la praxis habitual era recibir el sacramento ya en edad adulta?

La cuestión del bautismo de Mónica la ilumina -así nos parece- un texto posterior. Se trata de la escena, referida en el libro segundo de las

${ }^{27}$ Resulta extraño que Agustín no informe de las circunstancias del bautismo de su madre (cf. L. C. SEELBACH, «Das weibliche Geschlecht ist ja kein Gebrechen, sondern Natur». Die Frau und ihre Gottebenbildlichkeit bei Augustinus [Würzburg 2002], p. 41). De las diversas biografías de Mónica que hemos consultado solo la de Mons. Bougaud aduce como posibilidad una fecha, tomándola de otros autores: habría sido bautizada en torno a los 16 años, coincidiendo con el regreso de la población de Tagaste de la Iglesia donatista a la católica en el 348 o 349 (Historia de santa Mónica [Librería católica, Madrid 1952²], p. 56). Le sigue L. Cristiani (Santa Mónica [Paulinas, Mexico 1981], p. 13 y 19) aunque habla de 17 o 18 años. Los demás hagiógrafos dejan entender que recibió el sacramento al poco tiempo de nacer, aunque el hecho contraviene a la praxis dominante entonces. Agustín se limita a indicar, tras referir su muerte, que su madre había recibido el bautismo muchos (tot) años antes (9,34.35). ¿Cuántos? Tot es un indefinido, por lo que no puede tomarse aquí como criterio. Utilizado también en el relato de la conversión, indica 12 o 13 años $(8,30)$. L. Seelbach no toca el tema (cf. «Monnica»: Augustinus-Lexikon [Schwabe Verlag, Basilea 20122018] 4, p. 69-75). 
Confesiones, en que Agustín aparece ya pubescente en los baños públicos. Ante el hecho, el padre Patricio y la madre Mónica reaccionaron de forma diferente: el padre se mostró entusiasmado, soñando ya con tener nietos; la madre se estremeció ante la posibilidad de que el hijo pudiera tomar un camino torcido. Agustín justifica esa diferencia con la distinta condición personal de cada uno de ellos dentro de la Iglesia. A Mónica la presenta como ya bautizada, pero desde hacía poco; a Patricio como aún (adhuc) catecúmeno, también desde hacía poco (et hoc recens erat); de sí mismo dice que todavía no estaba bautizado, forma de indicar que era catecúmeno desde hacía ya tiempo (nondum fideli).

La claridad referente a Patricio y a Agustín falta respecto a Mónica. De ella afirma que Dios «ya había comenzado a levantar en el corazón de ella su templo y el principio de su morada santa». Ahora bien, de un lado, es fácil ver en la idea de templo y de morada una remisión al bautismo como sacramento por el que el receptor se constituye en templo y morada de Dios ${ }^{28}$; de otro, tanto el verbo inchoaveras ${ }^{29}$ como el sustantivo exordium hacen referencia a un comienzo. La conclusión que puede sacarse es que Mónica había recibido el bautismo no hacía mucho. Es cierto que, considerando que la vida cristiana es una carrera de larga duración, la referencia a un comienzo no im-

${ }^{28}$ La relación entre bautismo e inhabitación está expresada en este texto, aunque tardío: «Hay que reconocer que (el Espíritu) ayuda de un modo a aquellos en los que aún no habita, y de otro a aquellos en los que ya habita; pues a aquellos en los que aún no habita los ayuda para que acaben convirtiéndose en fieles (bautizados), y a aquellos en los que ya habita los ayuda siendo ya fieles (bautizados)» (ep. 194,18: Sed, quod fatendum est, (Spiritus) aliter adiuvat nondum inhabitans aliter inhabitans; nam nondum inhabitans adiuvat ut sint fideles, inhabitans adiuvat iam fideles).

Llama la atención el descuido de un hagiógrafo de la santa, que escribe así: «Pero tú, Señor ya habías comenzado a edificar tu templo en el corazón de mi padre y a tener allí tu santa morada; que mi padre todavía era catecúmeno desde hacía poco tiempo; y, así, al oírlo, se sobresaltó con piadoso temor y, pues, aunque todavía no era cristiano, temió que fuera por las torcidas sendas por donde andan los que te vuelven la espalda y no la cara» (A. MoRRÁs, San Agustín y Santa Mónica, p. 34).

${ }^{29}$ Sobre este verbo, cf. D. Wright, «Monnica's Baptism, Augustine deferred Baptism, and Patricius»: Augustinian Studies 29/2 (1998), 1-17:10. J. J. O’Donnell señala, a propósito del verbo, que nada indica aquí una piedad grande o de larga duración en Mónica, sino lo contrario. Añade que, en vista del contraste con Patricio en la línea siguiente, puede indicar solamente que ya había sido bautizada -pero puede significar también que lo ha recibido recientemente, como pensamos- y añade: «su actuar hasta aquí es la de una madre mundana» (Augustine Confessions. Volume II. Commentary. Books 1-7 [Clarendon Press, Oxford 1992] p. 121). 
plica necesariamente que ese comienzo sea reciente ${ }^{30}$. Pero en este caso hay un dato que indica que así ha de entenderse: a continuación, Agustín comienza a presentar a su madre como fiel (2,7: matrem meam, fidelem tuam), es decir, bautizada. Este dato tiene especial valor habida cuenta de que previamente nunca la ha presentado como fiel (fidelis) y que así lo hará ya en los libros siguientes (cf. 3,19: mea mater, fidelis tua; 5,15: illa fideli pectore $)^{31}$. El dato adquiere más fuerza, primero, si se considera que, al referirse a su madre, Agustín se había limitado a señalar la referencia a él, su hijo, y ahora añade la referencia a $\operatorname{Dios}^{32} \mathrm{y}$, segundo, si se advierte que la situación religiosa de la familia aparece ya diferente de la indicada en el libro anterior $(1,17)$ : entonces, Mónica y Agustín eran solo creyentes -catecúmenos-; Patricio estaba aún alejado de la fe; ahora -no se sabe cuánto tiempo más tarde-, la situación ha evolucionado en la misma dirección que el conjunto de la sociedad ${ }^{33}$ : Mónica y Patricio habían dado un paso hacia delante: ella ya había recibido el bautismo ${ }^{34}$; él se había

${ }^{30}$ La indicación de que fue Cristo quien la educó en «una casa de bautizados, miembro bueno de tu Iglesia» no implica que fuera bautizada de niña, porque lo habitual era el bautismo en edad adulta, salvo peligro de muerte inminente. Sobre las distintas posibles interpretaciones del sintagma entrecomillado, cf. D. F. WriGHT, «Monnica’s Baptism...», p. 10, n. 36.

${ }^{31}$ Lo mismo puede decirse del término «sierva (ancilla) del Señor» que comienza a referir a Mónica $(2,7 ; 5,18 ; 0,1.15)$.

32 Primero solo «mi madre» $(1,7 ; 1,9 ; 1,17$ [2]) y «la madre de mi carne» $(1,17)$; después, «mi madre, tu fiel» $(2,7 ; 3,19)$. En 2,8 , en cambio, Agustín vuelve a hablar de «la madre de mi carne», pero silenciando «tu fiel», sin duda porque desentonaba en el contexto, pues acababa de indicar que le costaba salir de «Babilonia».

${ }^{33}$ Cf. W. H. C. FrendT, «The Family of Augustine:A Microcosm of Religious Change in North Africa», en Congresso Internazionale su S. Agostino nel XVI centenario della conversione, Roma, 15-20 settembre 1986. Atti 1 (Roma 1987), 135-151.

${ }^{34}$ En cuanto a la edad concreta en que fue bautizada, A. Mandouze considera que es imposible determinarla, añadiendo que en todo caso Mónica pertenecía al número de los «fieles» en el momento del nacimiento de Agustín, remitiendo a conf.1,17 (Prosopographie de l'A frique chrétienne (303-533) [Paris 1982], p.759, n. 29). Adviértase que del pasaje entero nosotros hemos concluido justo lo contrario. La propuesta de D. Wright -que, habiendo estudiado el tema, señala que ha suscitado poco interés entre los investigadores- es muy prudente, al ser excesivamente genérica. Del modo como se expresa Agustín en las Confesiones (9,34-35), se puede inferir -juzga el autor- que tuvo lugar una vez que ella alcanzó la edad de la responsabilidad personal (o. c., 11). Nosotros, a partir de los datos aducidos, creemos que se puede concluir que Mónica podía haber superado los treinta años cuando recibió el sacramento de la fe. En efecto, Mónica habría sido bautizada no hacía mucho cuando Agus- 
hecho catecúmeno, Agustín no se había movido, pues seguía siendo catecúmeno.

Cuando Agustín acabó sus estudios en Cartago, regresó a Tagaste con dos voluminosos fardos que difícilmente podían entrar por la puerta de la casa de Mónica: uno de naturaleza religiosa -se había hecho adepto de la secta maniquea- y otro de naturaleza moral -había ligado su vida a una concubina que le había dado un hijo-. De hecho, fue el primero de ellos el que le impidió la entrada, no el segundo. Mónica le cerró las puertas de su casa por ser maniqueo, no por vivir en concubinato. Era lo primero lo que turbaba su sueño, no lo segundo, y precisamente en su tiempo de sueño recibió la visión en la que se le anunciaba el regreso del hijo a la fe $(3,19-20)^{35}$. El concubinato ni siquiera aparece mencionado. ¿Cabe, entonces, pensar en Mónica como una persona rigorista en cuestiones de fe, pero laxa en cuestiones de moral sexual? Agustín -es cierto- no lo dice, pero su silencio podría llevar a pensar que tal era la realidad. Un cierto laxismo parece haber manifestado en una etapa anterior de la evolución del hijo, cuando le recomendaba vivamente que no fornicara, por supuesto, pero, por encima de todo, que no adulterara $(2,7)^{36}$. Si la moral cristiana considera pecado grave tanto lo uno como lo otro, ¿qué sentido tiene esa distinción? ¿Acaso se debía a que el adulterio podía acarrear al

tín tenía 15 años cumplidos y ella, por tanto, unos 38. Y no parece fuera de lógica pensar que coincidieran en el tiempo el bautismo de Mónica y la entrada en el catecumenado de Patricio.

${ }^{35}$ Sobre los sueños de Mónica, cf. M. DulaeY, «Sogne et prophétie dans les Confessions d'Augustin. Du rêve de Monique à la conversión au jardín de Milan»: Augustinianum 28 (1989) 378-391. En cuanto a la interpretación de la escena, escribe la autora: «Es más próximo a la verdad atenerse a lo que dice Agustín mismo: el sueño de Mónica tiene un rol importante en su evolución. Por primera vez se halló ante la realidad de la fe cristiana, la posibilidad de que Dios hable al hombre, y la seguridad absoluta que produce» (p. 384).

${ }^{36}$ J. J. O’Donnell advierte aquí un cambio en el modo como Agustín presenta a Mónica. Según el autor, las anteriores referencias a ella, eran fundamentalmente indirectas, ofreciendo un cuadro tradicional de una madre asustada por la enfermedad del hijo, ávida de que avanzase en su carrera y preocupada a causa de su madurez sexual. En ello ve una crítica velada -(¿solo velada?, nos preguntamos)- de Agustín a sus padres por el modo como gestionaron esos asuntos (2,4.6.8). Su aparición aquí tras la muerte de su esposo la pone irreversiblemente en el rol que será suyo en adelante. Y se pregunta si no hay que asumir un florecimiento de la religiosidad en Mónica tras la muerte de Patricio (cf. Augustine Confessions, vol. II. p. 197). 
joven indeseables consecuencias penales que no acarreaba la simple fornicación? ${ }^{37}$. Rebajar de hecho la gravedad de la fornicación, ¿no era una forma de abrirle las puertas a la relación que, a poco de llegar a Cartago, estableció con una mujer de inferior categoría social? Es obvio que estamos ante una lectura posible, pero no la única. Cabe, en efecto, que Mónica tuviera que conformarse con el mal menor. Sabedora de que en el contexto concreto que Agustín mismo refiere $(2,7)$ le iba a ser imposible cortar en seco, se contentó con poner un freno al hijo; por otra parte, si en el plan del relato estaba contemplado que la concubina y el hijo no aparecieran hasta el libro cuarto, se entiende que Agustín no lo saque a relucir ya en el tercero.

En cuanto a la respuesta del obispo, antes señalada, que, según Agustín, tanto consuelo dio a su madre $(3,21)$, queda por saber si la entendió correctamente o si, de forma inconsciente, hizo una interpretación interesada. De hecho, no hay que excluir una respuesta esquiva de parte del jerarca eclesiástico, hastiado de la insistencia, por no hablar de impertinencia, de Mónica. En esa dirección parece ir la respuesta del obispo, que, al comenzar con un Vade a me, evoca las palabras de Jesús a Pedro Vade retro (Mt 16,23), y cuyo sentido probable es este: «Aléjate de mí -esto es: déjame en paz-, que no es posible que perezca un hijo que cuesta tantas lágrimas» $(3,20)^{38}$.

La huida a Roma de Agustín se ha interpretado como la cima de su plan para librarse de su posesiva madre ${ }^{39}$. Por otra parte, el empeño de

${ }^{37}$ En la medida en que seguía en vigor la ley Iulia de adulteriis coercendis, del año 18 a. C. Bajo determinadas condiciones y circunstancias podía acarrear incluso la muerte. Así resulta de la carta 199,34 de san Basilio Magno, aunque él se limita a hablar del caso de las mujeres. Sobre la legislación civil, cf. B. Rodríguez ARROCHA, «La concepción jurídica y moral del adulterio en Roma: Fuentes para su estudio»: Anales de la Facultad de Derecho 27 (2010) 127-138: 129-130; A. Rouselle, Porneia. Del dominio del cuerpo a la privación sensorial. Del s. II al s. IV de la era cristiana (Ediciones Península, Barcelona 1989) 95-110.

${ }^{38}$ Es irónico - escribe una autora- que la etiqueta tan asociada a Mónica como digna de elogio en la tradición fuera originariamente un comentario irónico de este viejo eclesiástico que estaba cansado de las quejas de Mónica y deseaba librarse de ella. Así, por medios humanos y divinos [el sueño] se invitaba a Mónica a respetar los tiempos de Dios» (K. Power, Veiled desire, p. 81. Cf. también L. SEelbaCH , «”Wie sollte ich selbst...», p. 307); M. DulaEY, «Sogne et prophétie...», p. 381.

${ }^{39}$ CF. L. SEeLBach , «"Wie sollte ich selbst...», p. 309. 
Mónica por impedir a toda costa que el hijo tomase rumbo a Italia o que, al menos, la llevase consigo ${ }^{40}$, podría interpretarse como consecuencia de su vivo deseo de que volviese a la fe católica, decisión que ella podría ayudar estando a su lado. Pero, según Agustín, no había más motivación que el simple afecto humano, «carnal» ${ }^{41}$. Al referir el hecho, lamenta haber recurrido a la mentira, pero no el no haberla llevado consigo. En el relato de la escena se muestra particularmente duro con ella. En su actitud ve, por una parte, un claro indicio de que no estaba familiarizada con el obrar de Dios (nesciebat..., nesciebat); por otra, advierte solo el amor «carnal» poco ha mencionado, es decir, puramente humano, no un amor específicamente cristiano ${ }^{42}$; además, las muchas lágrimas que Mónica derramó al

${ }^{40}$ El relato está sin duda muy estilizado al quedar reducido a solo dos protagonistas, el hijo Agustín y la madre Mónica. Es difícil pensar que Agustín no llevara consigo a la concubina y al hijo, habida cuenta, entre otras cosas, de dos afirmaciones suyas: que él le fue enteramente fiel $(4,2)$ y que era incapaz de vivir sin una mujer, esclavitud tal y tan larga que extrañaba sobremanera a Alipio (6,22). Ahora bien, ¿cómo es posible mantener la veracidad de ambas afirmaciones si no le acompañó la concubina, salvo que se entienda que le fue fiel mientras la tuvo a su lado, lo que desvirtuaría enteramente la afirmación? Dando, pues, por hecho que Agustín la llevó consigo a ella y al hijo - ¿cuándo fueron, si no entonces, pues ambos aparecen en Milán-?, y que ello equivalía a una mudanza, resulta difícil entender que Mónica estuviera tan ciega que no lo advirtiera y se dejara engañar de la forma indicada.

Por otra parte, la escena ha sido interpretada en clave psicoanalista con el trasfondo del libro cuarto de la Eneida en que Virgilio narra la fuga de Eneas a Italia dejando a Dido en la playa que acabó suicidándose. Cf. al respecto, A. SCHINDLER, «Verifying or Falsifying Psichohistorical Observations: The case of Dido's Suicide in Augustine's Confessions»: Studia Patristica, vol. XXXIII (Lovaina 1997) 239-243. El autor sostiene que Agustín siguió su propio camino -a más tardar desde el tiempo del concubinato y su paso al maniqueísmoy que mantuvo a su madre firme, aunque cortésmente, fuera de sus asuntos, de sus actividades, hasta su conversión. Luego, siguiendo a J. J. O’Donnell, señala que son más las semejanzas de Mónica con la madre de Euríalo que con Dido (p. 242). Cf. también C. BENNET, «The conversion of Virgil: The Aeneid in Augustine's Confessions»: Recherches Augustiniennes 34 (1988) 47-69. Aceptando que Mónica es una figura de Dido, señala también las diferencias entre ambas mujeres y también entre Mónica y la madre de Euríalo, otro personaje de la Eneida (p. 63-64).

${ }^{41}$ La motivación supuesta no tendría razón de ser, una vez que en la visión se le había asegurado la conversión del hijo, independientemente de que ella interviniera o no.

${ }^{42}$ No cabe duda que el adjetivo «carnal» no hay que entenderlo aquí en relación con la lujuria, sino con el amor puramente natural que sienten los padres por los hijos. Aunque son distintos los sujetos y el contexto, es similar a lo que prescribe en su Regla monástica: «el amor no ha de ser "carnal», sino espiritual» (praec. 6,3; cf. también Io. eu. tr. 65,1). El gran psicólogo 
verse engañada, las interpreta el hijo como justo castigo de Dios por su excesivo apego a él, puesto que -«como todas las madres y más que la mayoría de ellas»- deseaba tenerlo junto a sí. «Dios quiso castigar su deseo excesivamente "carnal" con el justo azote del sufrimiento». Los lamentos de la madre revelan, según el hijo, el fondo de Eva que había en ella, al buscar con gemidos lo que con gemidos había parido (conf. 5,15). Dicho brevemente, calificar su deseo de «carnal», interpretar su dolor como castigo de Dios y equipararla a Eva no permiten sostener una valoración religiosamente positiva del comportamiento de Mónica en la ocasión por parte de Agustín.

Ya en Milán, Mónica se sometió plenamente a las directrices del obispo Ambrosio relativas al culto de los mártires, que divergían del proceder que ella había seguido en África. En un primer momento Agustín pondera al máximo tal actitud; pero, acto seguido, rebaja el tono aduciendo la sospecha de que detrás de tal docilidad solo había un afecto personal hacia el pastor $(6,2)$. En terminología que él usa en otros contextos, tal comportamiento obedecía más a un amor «privado», que a un amor «común», es decir, un amor a Ambrosio, persona con la que tenía una relación particular, más que a Ambrosio, el pastor de todos ${ }^{43}$. Ahora bien, el afecto particular es algo que, por la misma época en que escribía las Confesiones, Agustín consideraba que había que repudiar (ep. 243,4). Así, pues, es Agustín mismo quien juzga que no todo era trigo limpio en su madre, aunque así lo pareciera.

Por último, señalamos la alegría desbordante que Mónica manifestó al conocer de boca del hijo el hecho de su conversión. Pero cabe preguntar si esa alegría era solo por la conversión en sí misma. El empleo por Agustín del verbo triumphare puede ser iluminador. El verbo latino significa menos triunfar que ser proclamado o proclamarse triunfador. Mónica

que era Agustín es consciente de que el amor de Mónica por él no era normal y lo revela con franqueza al referir la reacción de ella ante su partida. Mónica intenta eliminar la interacción entre presencia y ausencia que caracteriza las relaciones sanas y sustituirla por un modo de estar presente que casi ahoga a su hijo, haciendo que para él sea necesario separarse de ella. Es la opinión de C. G. Vaught (The Journey toward God in Augustine's Confessions: Books IVI, [Albany, Nueva York 2003], p. 129), que también compara a Mónica con Dido.

${ }^{43}$ K. Power (Veiled Desire, p. 64) advierte que la observación de Agustín plantea dudas sobre las razones de Mónica. 
triumphat, es decir, se adjudica un triunfo. ¿Qué triunfo? El triunfo en la disputa sobre las palabras del joven risueño que en una visión le anunció la futura vuelta a la fe católica del hijo, sobre cuya interpretación habían discutido ambos $(3,21)$ y a la que hace referencia acto seguido. La realidad había avalado la interpretación de Mónica y ella celebraba su triunfo. ¿No querrá Agustín indicar que su madre estaba sacándose la espina de que el hijo no hubiera dado fe a sus palabras? $(8,30)$. La seguridad que en su momento había mostrado se manifestaba ahora como desquite.

Hemos recorrido algunos de los hitos significativos del acompañamiento de Mónica a Agustín en su camino de regreso hacia la fe católica. Solo sumariamente hemos referido los aspectos más luminosos del acompañamiento hecho por Mónica a la vida religiosa de su hijo. No era preciso detenernos más porque son bien conocidos, pero sí poner de relieve los aspectos oscuros que Agustín mismo señala explícitamente o deja intuir.

\section{b) Mónica acompaña al hijo en su recorrido hacia el éxito social}

El recorrido hacia el éxito social lo hizo Agustín acompañado primero por sus padres y luego, cuando murió Patricio, por su madre. Por lo que se refiere al aspecto económico fue insustituible el apoyo recibido de su paisano y pariente Romaniano (acad.2,3), aunque a este lo silencia en las Confesiones, quizá para resaltar aún más el mérito de su madre viuda. A continuación presentamos juntos los hitos del acompañamiento por parte de su madre y la valoración moral que de ellos hizo el hijo.

Ese recorrido comienza con el envío del niño a la escuela local de Tagaste para que cursase los estudios primarios. Lo que llama la atención es que, antes de valorar positivamente la instrucción en ella recibida, emita un negativo juicio moral sobre las motivaciones por las que la impulsaban sus padres: «Siendo niño -escribe- se me proponía como norma de una vida recta la obediencia a mis maestros. El objetivo era conseguir renombre mundano y sobresalir en el arte del bien hablar, encaminado a obtener honores mundanos y a amasar falsas riquezas. En eso pensaban -se entiende que sus padres- cuando me enviaron a la escuela» $(1,14)$. La crítica a ellos es clara y directa. No va dirigida contra su escolarización, sino contra las motivaciones, enteramente mundanas, sin espacio alguno a consideraciones más elevadas. 
Etapa de singular importancia en este recorrido fue también la última etapa de la «niñez» ${ }^{44}$, acompañada del despertar del impulso sexual, cuya satisfacción fuera del matrimonio chocaba con la moral cristiana, a la que su madre quería que se atuviese. La crítica a los suyos -«los míos», en los que hay que incluir a sus padres, si es que no se refiere solo a ellos- aparece expresada aquí en el lamento de que su única preocupación (cura fuit tantum) era que aprendiera a componer discursos magníficos y a persuadir con la palabra, desentendiéndose de poner remedio a su desmadre sexual $(2,4)$. Según el obispo que escribe las Confesiones, la solución consistía en orientarle hacia el matrimonio, opción legalmente viable y socialmente aceptable a su edad ${ }^{45}$. La dificultad radicaba en que -en opinión de sus padres- tal solución ponía en peligro avanzar por la ruta del éxito social, al que iba unido el económico. Daban por hecho que contraer matrimonio equivalía a decir adiós a los estudios y a una brillante carrera civil ${ }^{46}$. Puestos ante la necesidad de decidir, no solo el ya catecúmeno Patricio, sino también la ya bautizada Mónica, antepusieron la carrera del hijo a una vida ajustada a la moral católica que ella trataba de inculcarle ${ }^{47}$. Los motivos de uno y otra eran -en opinión de Agustín- diferentes: Patricio porque construía castillos en el aire respecto del hijo, Mónica porque juzgaba que los estudios le ofrecerían no pequeña ayuda para llegar a Dios. Agustín reconoce que se trata solo de conjeturas suyas a partir de las costumbres de sus padres. La motivación atribuida a su madre era una

${ }^{44}$ La niñez para los romanos duraba desde los 7 hasta los 17 años, en que alcanzaba la mayoría de edad política, momento en que entraba en la adolescencia.

${ }^{45}$ La edad núbil para la mujer comenzaba a los 12 años y para el varón a los 14 . Agustín había cumplido ya los 15 años $(2,6)$.

${ }^{46}$ Entendida también, muy probablemente, como una inversión que se vería recompensada con frutos, no solo para Agustín mismo, sino también para la familia (cf. K. Power, «Familia. parientes», en A. D. FitzGerald (dir.), Diccionario de san Agustín. Traducción al español de C. Ruiz-Garrido [Ediciones Montecarmelo, Burgos 2001] 556-558: 557).

${ }^{47}$ La doble convicción de Mónica de que el matrimonio sería un impedimento serio para la formación del hijo y de que los estudios le ayudarían a llegar a Dios, junto con la observación de que, de forma insistente, ella puso a su hijo en guardia contra el desenfreno, sirve para justificar su decisión (cf. L. SEELBACH, «Agustín y Mónica: las líneas maestras de una relación que definió las líneas maestras de una vida», en T. J. vAN BAVEL - B. BRUNING [ed.], San Agustín [Instituto Histórico Agustiniano, Heverlee 2007] 25-27: 26; ID., «"Wie sollte ich ...», p. 307). ¿Será que el fin justifica los medios? 
especie de justificación «salvadora», necesaria después de haberla presentado antes como su madre «carnal», como indicando que de ella solo había recibido la carne, desentendiéndose de su espíritu $(2,8)$,

Ironías de la vida, el camino que sus padres le cerraron, lo abrió él poco después, ya en Cartago, lejos de ellos, al tomar una concubina, sin que ello le impidiese un brillante currículum académico $(4,2)$. La preocupación de la madre por la carrera mundana del hijo se había impuesto entonces a los ideales morales de ella. La vanidad fundada en esperanzas mundanas halló en el corazón de Mónica un puerto tan cómodo -si no más- como el de su marido pagano ${ }^{48}$. Mónica miraba por el futuro de su hijo, pero no el eterno, sino solo el terreno e inmediato -es Agustín mismo quien lo dice- $(2,8)$. Los lectores y hagiógrafos suelen ignorar la crítica del hijo ${ }^{49}$, ocultarla bajo otras manifestaciones de virtud y devoción de Mónica ${ }^{50}$, o justificar el actuar de Mónica por el contexto social ${ }^{51}$, o por el amor de madre a la que se permiten cosas que no se permiten a otros.

Más importante para el objetivo de nuestro estudio es lo que Agustín ha escrito inmediatamente antes. De sí mismo afirma que en aquel momento de su vida pateaba las calles de Babilonia y se revolcaba en su fango como si se tratase de ungüentos preciosos. Más aún, que un enemigo invisible lo pisoteaba en el mismo centro -ombligo- de la ciudad. De su madre, en cambio, afirma que ya había huido del centro, pero que tardaba en abandonar su territorio $(2,8)$. En otras palabras y manteniendo la imagen, que había salido de la plaza mayor, pero no de sus suburbios. Solo teniendo en cuenta el calificativo de madre de las rameras y de las

${ }^{48}$ Cf. R. J. O'Connell, Images of conversion, p. 63.

${ }^{49}$ Es el caso, por ejemplo, G. Saginario (Monnica mia madre. Biografia critica della madre di Agostino [Città Nuova Roma 2005]), olvida la indicación de Agustín, que señalamos a continuación, de que Mónica se hallaba en los «suburbios de Babilonia». Así queda libre para hacer una encendida defensa de la actuación de Mónica (pp. 134ss.), que no se compadece con lo que dice Agustín. Cf. también L. C. SEELBACH, «Das weibliche Geschlecht; A. Morrás, San Agustín y Santa Mónica (Ediciones Paulinas, Venezuela 1986); M. LARRíNAGA. Santa Mónica (PPC, Madrid 1986).

${ }^{50}$ Cf. J. J. O’Donnell, Sant'Agostino, p. 63.

${ }^{51}$ Según K. Power, Agustín se toma tantas molestias para mostrar a Mónica como enteramente sumisa al marido, que considera que sería improcedente cualquier reproche, añadiendo que quizá no quiso casarlo tan joven, a la vista de las infidelidades de su marido (Veiled desire, p. 79); cf. también, A. MorRÁs. San Agustín y Santa Mónica, p. 55. 
abominaciones de la tierra (Apoc 17,5) y que, en conformidad con la tradición cristiana, Agustín considera a Babilonia como el símbolo de la ciudad y sociedad de los impíos (cat. rud. 37; en. Ps. 26,2,18), se puede calibrar en sus justos términos el dato que, en clave moral, aporta de su madre. Pero ¿qué significa estar en el centro de esa ciudad? Lo podemos deducir del contexto: Agustín se hallaba en él por su sumisión a la lujuria de la que ha hablado inmediatamente antes; Mónica, en cambio, ya había abandonado el centro de la ciudad en cuanto que había exhortado al hijo a guardar la castidad; en cambio, en lo demás iba más lenta (in ceteris eius ibat tardius) puesto que, por temor a que se frustrase su carrera, no se apresuró a mantener dentro de los límites del afecto conyugal sus impulsos sexuales. En otros términos, Mónica se presentaba sí, como muy amante de la castidad, pero no lograba desprenderse de la ambición que ocultaba el hecho de ser capaz de sacrificar valores morales -y con ellos la vida eterna del hijo- en pro de su prestigio social y económico ${ }^{52}$. En este sentido Mónica se hallaba aún en los suburbios de Babilonia, situación que iba a durar (tardius), como señala el obispo Agustín ya a toro pasado ${ }^{53}$. Este juicio invita a leer con ojos distintos de los habituales el panegírico que le dedica en el libro noveno.

En realidad, sin embargo, la afirmación de Agustín parece ser un atenuante a la acusación vertida contra la madre, si se tiene en cuenta lo que él ha afirmado poco antes. Si Mónica había sido bautizada hacía poco tiempo o si Dios, según el mismo Agustín, solo «había comenzado a construir su templo en ella», no extraña tanto que siguiese aún en los suburbios de Babilonia, aunque hubiera abandonado ya el centro de la ciudad. La situación explicaría de alguna manera el anteponer los intereses mundanos a los morales en relación con el hijo. A su vez, ese poner en segundo lugar los intereses morales se podía justificar a los ojos de Mónica por el hecho

${ }^{52}$ Téngase en cuenta que Agustín presenta explícitamente las recomendaciones hechas por Mónica a su hijo, como recomendaciones de una bautizada -primera indicación explícita en la obra-, por la que ya hablaba Dios: Et cuius erant nisi verba tua illa per matrem meam, fidelem tuam, quae cantasti in aures meas? $(2,7)$.

${ }^{53}$ Según M. Djuth, el uso de la metáfora de Babilonia para singularizar las imperfecciones de Mónica humaniza a Mónica. Revela a la vez que incluso la conversón de Mónica al cristianismo en una obra en progreso desde el momento en que Babilonia continúa atrayéndole, aunque difícilmente en la medida en que a Agustín (cf. «Augustine, Monica and the Love of Wisdom»: Augustinian Studies 39 [2008] 237-252: 250). 
de que su hijo aún no había recibido el bautismo, confiando en que acabaría recibiéndolo y que entonces se le perdonarían todos sus pecados $(1,18)$. En definitiva, la misma lógica por la que quiso postergar el bautismo que le solicitó su hijo, aún niño, sería la que le llevó a anteponer la carrera académica del hijo a que se adecuase a la moral cristiana. Ella no había hecho más que comenzar a recorrer el camino como bautizada y se comprende que su progreso fuese limitado. Solo que su hijo lo percibe como una mancha en el vestido blanco que la madre había recibido en el bautismo.

Agustín se trasladó a Italia en el año 383, engañando y dejando plantada a su madre en el puerto de Cartago. Casi dos años después, Mónica atraviesa el Mediterráneo, recorre parte de Italia y encuentra al hijo en Milán. En su relato pone de relieve la seguridad de Mónica de que Dios la libraría de los peligros, hasta el punto de infundir ánimo a los marineros que temían por su vida en medio de una gran tormenta marina $(6,1)$. No cabe duda de que el motivo del viaje era encontrar al hijo. Pero ¿cuál era el trasfondo de esa decisión? La indicación de Agustín de que fue el gran amor materno el que le otorgó la fortaleza para emprender una travesía tan dura y arriesgada (mater pietatte fortis), trae a la mente lo escrito al referir la fuga en Cartago: «Como las demás madres, y mucho más que muchas de ellas, amaba tenerme consigo» $(5,17)$. La diferencia está en que mientras entonces hablaba de un «deseo carnal», ahora habla de un «sano amor materno» (pietas). ¿Ha sido acaso la constancia de la madre lo que ha llevado a Agustín a valorar diversamente su empeño en «seguirle por tierra y mar»? Una motivación específicamente religiosa está ausente aquí, como ya antes en Cartago. En realidad, ya no tenía mucha razón de ser, una vez que el joven de la visión le había anunciado la futura vuelta del hijo a la fe católica como ya indicamos. Es de suponer que, en la mente de Agustín, esta era la razón por la que ni se inmutó cuando el hijo le informó de que ya no era maniqueo. Es cierto que ella siguió moviéndose con ese objetivo en mente, tratando de implicar en él al obispo Ambrosio (6,1-2), aun sabiendo que el objetivo se cumpliría, actuase ella o no. Pero no hay por qué excluir una motivación añadida. Es lógico suponer que Mónica no hizo el viaje sola. Dado que en el momento de su muerte aparece junto a Agustín su hermano - ¿Navigio?- $(9,27)$, parece sensato pensar que con ella viajaron él y los primos Lartidiano y Rústico, también presentes en Casiciaco (b. uita 6). El dato suscita la pregunta de si la intención principal del viaje no era vivir ya a la sombra del hijo y gozar de 
su nueva posición social. De ser cierta esta hipótesis, se abre una nueva perspectiva: la devota Mónica no pensaba solo en el éxito social y la vuelta a la fe del hijo, sino también en ella misma y otros miembros de la familia. En otros términos, ¿no habría ido a recibir los réditos de la «inversión» hecha en otro tiempo?

Lo que acabamos de decir es solo una hipótesis, pero que cuadra perfectamente con otro dato bien conocido. En efecto, el despido de la concubina de Agustín ${ }^{54}$, consecuencia de la concertación de matrimonio con una joven católica y de condición social acomodada, se cruza siempre en cualquier discurso sobre Mónica. Mónica y Patricio habían tenido claro que el camino hacia el éxito social tenía su ineludible punto de partida en la escuela. Una brillante carrera académica era llave que posibilitaba el acceso al círculo reducido de los privilegiados de la sociedad imperial. Pero, llegado el momento, madre e hijo advirtieron que, en su caso concreto, se requería una segunda llave: un matrimonio de altura, que aportase categoría social y bienestar económico, con vistas al cual el concubinato en que vivía Agustín, sin duda legal, se convertía de facto en un impedimento $(6,25)$. Mónica se movió con habilidad para concertar un matrimonio de esas condiciones con una joven católica ${ }^{55}$, no faltando quienes, sin usar el término, han considerado a Mónica como una Celestina ${ }^{56}$. Lo que no deja de causar extrañeza es cómo una mujer «de pueblo», llegada pocos meses antes a la ciudad residencia imperial, y además africana, logró moverse tan activamente en la alta sociedad milanesa. Pero

${ }^{54}$ Sobre el status legal y eclesial del concubinato, cf. K. Power, « Sed unam tamen: Augustine and his concubine»: Augustiniam Studies 24 (1944) 49-76: 50-56.

${ }^{55}$ Que Agustín se casase con una mujer cristiana junto con su aceptación del bautismo cristiano resumen, según E. Ann Matter, el interés espiritual de Mónica por su hijo (cf. «Mujeres», en A. D. FitzGerald (dir.), Diccionario de san Agustín, p. 913-922: 916).

${ }^{56}$ En relación con la intervención de Mónica en el proyecto de matrimonio de su hijo, las perspectivas de los autores son diferentes. Por ejemplo, según K. Borresen, Mónica forzó el despido de la concubina para asegurar la carrera del hijo como gobernador provincial y casarse con una rica heredera («Patristic "Feminism”: the Case of Augustine»: Augustinian Studies 25 (1994) 139-152:139. Otros autores, en cambio, la justifican (cf. nota siguiente). J. Lössl, a su vez, presenta una perspectiva distinta. Según él, Mónica no intervino movida por ambiciones personales, sino que se limitó a cumplir con su deber actuando como cabeza de familia que era desde la muerte de su marido. Tal era, al menos, la práctica habitual; además se lo había pedido explícitamente su hijo («Augustine's family as space of religious experience»: Augustiniana 54 [2004] 401-415: 408). 
la «rosa» encontrada por Mónica tenía, como todas, su espina, que consistía en que la futura consorte contaba solo 10 años y, para cumplir con el mínimo exigido por la ley, el matrimonio debía postergarse dos años. Lo que estaba en juego no era solo el éxito del hijo sino el bienestar económico y, en cierto modo, también el prestigio social de la familia entera ${ }^{57}$.

Partimos de que la decisión fue consensuada entre madre e hijo, aunque luego quien más se movió fue ella. Lo que ahora interesa señalar es que Agustín, ya obispo, no bendice la operación desde una perspectiva estrictamente religiosa. Incluso Mónica dudó de que su gestión hubiese contado con la aprobación divina. La prueba la ven en que Dios, que en otros casos le había manifestado su voluntad por medio de sueños, en el presente había guardado silencio a pesar de haberle suplicado repetidas veces una señal al respecto. A falta de respuesta, Mónica -dice Agustín- se recreaba en visiones, que no tenían el sabor de lo divino $(6,23){ }^{58}$. Lo lógico es relacionar esos sueños con el éxito social de su hijo: aunque aún faltaban dos años para que se hiciese realidad el matrimonio concertado, ella vería a su hijo elevado a una alta magistratura del Imperio y con el problema económico resuelto, doble situación de la que ella confiaba sacar beneficio para sí misma y para el resto de la familia. Agustín, una vez más, acude en socorro de la madre, señalando que ella se alegraba de verlo cada día más apto para el bautismo y que con la recuperación de la fe católica por parte del hijo se cumplirían sus deseos y las promesas divinas $(6,23)$. Es significativa la neta distinción entre los deseos de Mónica (vota) y las promesas divinas (promissa). Si resulta claro que las «promesas divinas» remiten a la predicción del joven del sueño de que él se encontraría en la misma regla de la fe que su madre $(3,19-20)$ y la del obispo de que no podía perecer el hijo que estaba costando tantas lágrimas $(3,21)$, también es claro que los deseos de Mónica correspondían al doble objetivo

${ }^{57}$ Sobre la decisión se ha escrito abundantemente. Muchos autores han juzgado con dureza a Mónica, pero otros consideran que solo se puede llegar a juzgar equilibradamente su comportamiento si se consideran las circunstancias sociales y la situación legal, a nivel estatal, de la época. Cf. A. Zumkeller, «Die geplante Eheschließung Augustins und die Entlassung seiner Konkubine. Kulturgeschichtlicher und rechtlicher Hintergrund von conf. 6,23 und 25», en A. Zumkeller (ed.), Signum Pietatis. Festgabe für Cornelius Petrus Mayer OSA zum 60. Geburtstag (Würzburg 1989) 21-35: 22); G. DEL EsTAL, San Agustín y su concubina de juventud (EDES, Sal Lorenzo de El Escorial 1996).

${ }^{58}$ Esa falta de seguridad permite suponer una conciencia intranquila. 
de que el hijo contrajese matrimonio (iustae nuptiae) con aquella joven milanesa y que pudiese seguir su escalada social. Simples deseos mundanos que justifican el que ella hablase de visiones vanas e ilusorias (vana et phantastica); puros sueños de un alma obsesionada con el asunto (de hac re satagens) $(6,23)$, que Dios no atendía, Se puede concluir, pues, que Agustín ve a su madre nadando a la vez en aguas cristianas y en aguas mundanas. En definitiva, la «piedad» de la devota Mónica se manifestaba no solo en el vivo deseo de que su hijo recibiera el bautismo, sino también en la ambición de verlo ascendido a la alta y opulenta sociedad imperial. El hijo, por respeto a la madre, no lo afirma explícitamente, pero permite al lector sacar esa conclusión.

Todavía un detalle. No cabe duda de que Mónica deseaba ver a su hijo bautizado en la Iglesia católica (fidelem catholicum) y que tenía la certeza, fundada en Cristo, de que así lo vería antes de abandonar ella este mundo (6,1). Sin embargo, según las Confesiones, Mónica nunca antes ha hablado del bautismo del hijo como posibilidad real concreta. Cuando tuvo la oportunidad, siendo niño él, la desechó por las razones conocidas $(1,17)$. Siempre según las Confesiones, Mónica solo comienza a ver posible el bautismo del hijo en el momento en que se decide a contraer matrimonio; previamente su preocupación estaba centrada en que volviese a la verdad católica, aceptando la fe. Y se entiende en su lógica: una vez contraído matrimonio, cauce lícito para la satisfacción de sus impulsos sexuales, ya podía recibir el bautismo sin peligro de dañar o empañar la imagen de Dios $(1,17)$. Quizá por eso nunca, según las Confesiones, le afea que conviviese con una concubina ${ }^{59}$ ni que, abandonada la primera, se buscase una segunda $(6,25)^{60}$. Hasta podría pensarse que Mónica estaba a gusto

${ }^{59}$ Si Mónica recurre a obispos para que hablen con el hijo $(3,19)$ es porque le preocupa su situación religiosa-era maniqueo-, no su situación moral -vivía en concubinato-. La muerte del hijo que ella contemplaba $(3,19)$ la asociaba a su condición de maniqueo, no a su inmoralidad. De hecho, en el libro cuarto afirma explícitamente que su madre le lloraba por haber caído en aquellas fábulas supersticiosas y perjudiciales $(4,7)$, y en el quinto, que el corazón de su madre nunca hubiera sanado en el caso de que la enfermedad que sufrió al llegar a Roma le hubiese llevado a la muerte, pero se refiere al hecho de no haber recibido al bautismo, aunque con mención explícita de su condición de maniqueo, no de su concubinato $(5,16)$.

${ }^{60}$ ¿Cabría pensar que Mónica siguió la «lógica» que Agustín formula en estos términos: «Déjalo hacer, que aún no está bautizado» y que critica como equivalente a decir: «Dé- 
con ambas porque eso significaba que él se atenía a lo que le había recomendado tiempo atrás, esto es, que al menos no adulterase $(2,7)$.

Hemos recorrido los hitos más significativos del acompañamiento de Mónica a Agustín en su recorrido en búsqueda del éxito social y hemos podido ver -igual que en el recorrido hacia la fe católica- que él no ha evitado la crítica a su madre, cuando ha creído que estaba justificada.

\section{c) La conversión de Mónica}

La intervención de Mónica en los dos recorridos de su hijo Agustín permite concluir que también ella necesitaba una conversión. Tal es precisamente la conclusión de Agustín que cierra el relato de la propia conversión con la conversión de su madre.

Efectivamente, el último parágrafo del libro octavo de las Confesiones menciona dos conversiones: una que tiene por objeto a Agustín y otra que tiene por objeto a Mónica ${ }^{61}$. Lo habitual es fijarse solo en la conversión del hijo y pasar por alto la conversión de la madre. Ambas conversiones tienen en común, primero, que, en la interpretación del ya obispo de Hipona, son obra de Dios -de ahí que hablemos de objeto y no de sujeto, pues quien escribe es ya el doctor de la gracia- y, luego, el corresponderse con los dos recorridos que hemos venido indicando, pero divergen en el modo como afectan al hijo y a la madre.

La conversión de Agustín representa el final de ambos recorridos, pero un final distinto en cada caso. Representa el final del recorrido hacia la fe católica, porque la decisión de recibir el bautismo constituye su

\footnotetext{
jale que se haga aún más daño, pues aún no está curado»? (1,18). Es significativo que esta crítica la haya vertido precisamente hablando de la negativa de su madre a administrarle el sacramento del bautismo, una vez curado. A esta posibilidad parece oponerse la viva recomendación de que se mantuviese casto, aunque aún no estaba bautizado (quamvis nondum fideli) $(2,6)$.

${ }^{61}$ De una conversión de Mónica, anticipada por la de Agustín, habla también P. Rigby («Was Augustine a narcissist?»: Augustinian Studies 44 (2013) 59-91: 68); M. DJUTH, «Augustine, Monica and the Love of Wisdom», p. 250. M. More O'Ferral se detiene en la conversión de Mónica, pero entiende por tal la renuncia a beber vino después de haber sido sorprendida por la esclava bajo cuyo cuidado estaba $(9,18)$ (cf. «Monica, the mother...», p. 28-30). Sobre el motivo por el que Agustín espera al libro noveno para narrar esta falta de Mónica, cf. L.C. SEELBACH, «Das weibliche Geschlecht, p. 36-37.
} 
mismo núcleo; representa también el final del recorrido hacia el éxito social, porque significó su renuncia a él. Ambos aspectos están recogidos en este texto en que Agustín habla de sí mismo: «Porque de tal modo me convertiste a ti, que ya no apetecía esposa ni abrigaba esperanza alguna de este mundo -fin del recorrido hacia el éxito social-, estando ya en aquella regla de fe, sobre la que hacía tantos años me habías mostrado a ella (su madre) -fin del recorrido hacia la fe católica-» $(8,30)$. En la presentación de su conversión, Agustín ha hecho uso del doble significado del término «fin» que repetidamente ha expuesto a sus oyentes o lectores: el fin como consunción -se acabó el pan-y el fin como plenitud -se acabó de tejer el vestido- (cf. s. ep. Io. tr. 10, 5; s. 53,6;358,4, etc.). Entender en esta clave la conversión de Agustín no ofrece dificultad. No sucede lo mismo con la conversión de Mónica en la que no es tan fácil advertir el doble aspecto.

Esta conversión la refieren estas palabras: «Y convertiste -siempre Dios-su duelo en gozo, más abundante que el que ella había deseado, y más valioso y limpio que el que ella buscaba en los nietos de mi carne» ( $I b$.). Lo primero que salta a la vista es que no aparece directamente como una conversión de la persona en cuanto tal, sino como conversión de su sentimiento de duelo en sentimiento de gozo. Para entender el texto es preciso tener en cuenta que el duelo es el signo externo del intenso dolor que produce una muerte $(4,14)$. Eliminada la muerte, desaparece el motivo del duelo. Pero ¿cuál era el motivo del duelo de Mónica? El texto habla de duelo en singular, pero ofrece un doble motivo. Así, al menos, cabe deducir de los dos tipos señalados de gozo, calificados diversamente -uno «más abundante (uberius) y otro «de más valor» (carius) y «más limpio» (castius)- y, sobre todo, del empleo de dos verbos en tiempos diversos -pluscuamperfecto: «había deseado» (voluerat) y copretérito: «esperaba» (requirebat)-. Es lógico pensar que, detrás de dos motivos de gozo, hay dos motivos -ya desaparecidos- de duelo, los que responden, respectivamente, a las dos muertes: la muerte del Agustín alejado de la fe católica y la muerte de Agustín en búsqueda de promoción y prestigio sociales ${ }^{62}$. Aquí revisten particular importancia los tiempos de los dos verbos señalados. Agustín se sirve primero del pluscuamperfecto, para indicar algo anterior al momento - pasado ${ }^{63}$ - de que está ha-

${ }^{62}$ Aunque también aquí se trata del «fin» de dos recorridos, en ambos casos hay que entender el término en su significado de «consunción».

${ }^{63} \mathrm{El}$ momento en que le dio a conocer su conversión. 
blando y luego de un copretérito, para indicar algo simultáneo al momento -también pasado- de que está hablando. Lo que había deseado, pero ya no deseaba, por ser ya una realidad, era sin duda la vuelta del hijo a la fe católica; lo que entonces aún seguía buscando eran los nietos que le pudiera dar Agustín, lo que en el caso concreto implicaba que contrajese el matrimonio ya concertado. La conclusión que puede extraerse es que la conversión de Agustín significó para Mónica una satisfacción -el hijo volvió a la fe católica, aceptando recibir el bautismo, como ella siempre había deseado-, y una frustración -el hijo decidió renunciar al matrimonio que ella había concertado, con todo lo que implicaba para él y para ella- ${ }^{64}$.

Llegados aquí, cabe preguntar en qué consistió en concreto la «conversión» de Mónica. No hay duda de que ella había deseado intensamente que Agustín volviese a la fe católica que le había inculcado de niño y que la sellase con el bautismo, pero sin pensar que ello iba a alterar su recorrido en la vida social. No parece que hubiera pasado nunca por la mente de la madre que, al dar tal paso, el hijo optase por vivir como siervo de Dios con sus consecuencias ${ }^{65}$. Este segundo aspecto de la decisión de Agustín significaba para Mónica la muerte del hijo coronado de éxito en la sociedad del Imperio y, con ella, la muerte de sus -de Mónica- esperanzas mundanas. También esta muerte explica el duelo de su madre que, según Agustín, Dios convirtió en gozo. La conversión de Mónica consistió en renunciar a más nietos, a una más elevada condición social y económica, inseparable de la promoción social de su hijo ${ }^{66}$. Teológicamente esa conversión la interpreta el hijo como una resurrección, habida cuenta de que el texto bíblico utilizado -Convertiste mi duelo en gozo (Sal 29,12)lo refiere a la muerte (duelo) y resurrección del Señor y de la Iglesia (gozo) (en. Ps. 29,1,12;29,2,21) ${ }^{67}$. En imagen con trasfondo psicológico la

${ }^{64}$ Mónica confiesa que Dios le dio más de lo que había pedido, porque solo le había pedido que su hijo volviese a la fe católica, no que renunciase al matrimonio. Pero esta percepción llegó solo a posteriori, una vez que ella aceptó la doble decisión de su hijo. Cabe pensar, pues, que en el relato Agustín hace, a posteriori, una recapitulación global de lo sucedido entonces.

${ }^{65}$ En caso contrario carecería de sentido su empeño en buscarle una joven con la que pudiera contraer matrimonio, pensando que ello favorecería su bautismo.

${ }^{66} \mathrm{El}$ mismo movimiento de ideas: la persona se convierte y Dios aleja de ella un mal, cambiándolo en gozo, aparece en ep. 104,11.

${ }^{67}$ En el «saco rasgado» de la continuación del salmo (Rasgaste mi saco y me ceñiste 
conversión aparece como un desnudarse del traje de duelo y vestir el de gozo y alegría. Los comparativos que en el texto califican este gozo -“más valioso, más limpio"- tienen la función de justificar ese cambio de vestido. El gozo que Dios le otorgó es de más valor (carius) y más limpio (castius) -no manchado por la concupiscencia de la carne- que el que Mónica venía buscando. Mónica, ya bautizada, había acabado como su esposo Patricio aún catecúmeno: suspirando por nietos de la carne $(8,30 ; 2,6)$. En el caso de Patricio Agustín había emitido un explícito juicio negativo al considerar ese deseo como fruto de la embriaguez con que este mundo se olvida del creador y ama en su lugar a la criatura $(2,6)$; con su madre se muestra más suave pero el mensaje viene a ser el mismo, al hablar de su sentimiento de duelo, convertido por Dios en sentimiento de gozo.

Así, pues, la conversión de Agustín conllevó la conversión de Mónica. Al renunciar él al matrimonio proyectado y hacer así inviables las esperanzas mundanas de su madre, vinculadas a él, no le quedó más remedio que renunciar a ellas. Se podría decir que hizo de la necesidad virtud. Para el hijo se había cerrado definitivamente el recorrido mundano y definitivamente se había introducido en el de la fe y vida en la Iglesia católica. De manera similar para Mónica se había cerrado el recorrido esperado y se había abierto definitivamente otro, siempre, por supuesto, dentro de la fe católica ${ }^{68}$. Si, indudablemente, la madre fue instrumento de Dios para que Agustín retornase a la fe católica, el hijo fue igualmente instrumento para revertir hacia Dios los deseos más mundanos de la madre.

\section{Análisis de Confesiones 9}

Por su misma naturaleza, la conversión es un punto de llegada, pero también un punto de partida. Lo que precedió a la misma, ya lo hemos

de alegría) lo interpreta como el deponer el peso de las ganancias de este mundo» (s. 326,1), justamente lo que acaba de hacer Mónica.

${ }^{68}$ Por eso no comulgamos enteramente con A. Trapè cuando afirma, refiriéndose al momento de la conversión: «Termina con él una gran misión y comienza otra más grande: termina la misión de Mónica, la madre que salva, y comienza la de Agustín, el amante de la sabiduría» (Vida de Santa Mónica , p. 36). Por una parte, Agustín quiere dejar claro que fue Dios quien lo salvó, no su madre; por otra parte, Mónica aún debía llevar a término la obra de Dios en ella. 
visto; ahora queda por examinar lo que la siguió. La conversión de Agustín tuvo un componente religioso, uno moral y otro espiritual, cada uno sellado con una decisión: la de recibir el bautismo en la Iglesia católica -el religioso-, la de poner fin a la sumisión a la lujuria y a toda ambición mundana -el moral-y la de vivir como siervo de Dios -el espiritual-. En la de Mónica, en cambio, falta el componente religioso por ser innecesario, pero se da el componente moral y el espiritual, caracterizados por la decisión de renunciar a ambiciones mundanas -el moral-, y de no buscar otro gozo que el que proviene de Dios -el espiritual-. Se habla de la conversión como punto de partida porque las decisiones que la definen requieren verificación práctica. Solo entonces deja de ser simple deseo o propósito para manifestarse como realidad. Agustín se encarga de verificar uno y otro aspecto de la conversión de su madre en el libro noveno de las Confesiones, primero el espiritual y luego el moral. Seguimos ese orden.

\section{a) Verificación de la conversión espiritual}

En los capítulos octavo y noveno del libro noveno de las Confesiones (§§ 17-22), Agustín ha referido los dones con que Dios enriqueció a su madre a lo largo de su vida, pero centrándose únicamente en las relaciones armoniosas con las personas de su entorno inmediato, a excepción de él, el único, al parecer, con el que su relación había tenido cierto grado de conflictividad ${ }^{69}$. Agustín ofrece una información que el lector agradece, pero no exigida por la trama de la obra centrada sustancialmente en las relaciones entre madre e hijo ${ }^{70}$, salvo para poner de relieve el contraste entre las relaciones de ella con los demás y las relaciones con él, dejando así clara la singularidad de su caso ${ }^{71}$. Con el capítulo décimo (\$§ 23-26), el relato re-

${ }^{69}$ La excepción la representa el último punto en que Agustín presenta a su madre ya en relación con el grupo del que él forma parte, una vez bautizado. De todos modos el texto resulta oscuro (cf. la discusión en D. Wright, «Monnica’s baptism ...», p. 6-8).

${ }^{70}$ En esas relaciones entre madre e hijo solo han interferido, Patricio -algo lógico por su doble condición de marido y padre-, y dos obispos, uno africano $(3,21)$, y el de Milán Ambrosio (6,2). Se puede contar también a Alipio, pero solo como acompañante $(8,30)$.

${ }^{71}$ Los autores aducen explicaciones diversas de la ubicación aquí de esta minibiografía de Mónica. K. Paffenroth, por ejemplo, ha observado justamente que en ella Agustín no refiere nada que tenga que ver directamente con Agustín y que el relato podía haberlo incluido en cualquier otro lugar o incluso haber prescindido de él, porque no tiene conexión con nin- 
cupera el formato de los ochos primeros libros en el sentido de que de nuevo vuelven a aparecer como protagonistas la madre y el hijo, en cuanto a miembros de la familia se refiere ${ }^{72}$. El texto ofrece la verificación del aspecto espiritual de la conversión de la madre -es de ella de la que viene hablando y de la que seguirá hablando luego-y, a la vez, de la de Agustín. Aunque se trata de una escena específica, localizada en el espacio y en el tiempo-denominada habitualmente «Éxtasis de Ostia» ${ }^{73}$-, de ella se sirve el ya obispo de Hipona para presentar la nueva situación espiritual de su madre, olvidada ya de los nietos que hubiera podido darle su hijo.

$\mathrm{El}$ primer detalle que procede ponderar en el relato es precisamente el recurso al texto paulino de Fil 3,13 (olvidando las cosas pasadas y proyectados hacia lo que está por venir). Con la cita señala la nueva situación, caracterizada por la superación del pasado y el mirar ya solo hacia adelante. La nueva relación entre madre e hijo no está condicionada por el pasado sino regulada en función del futuro -el presente se esfuma en el mismo instante de aparecer-.

Precisamente esa nueva relación es un indicador de la realidad de la conversión, en cuanto que significa la reconciliación plena y definitiva entre madre e hijo. Que ambos conversasen con suma dulzura muestra que el pasado había sido superado. Mónica y Agustín ya están juntos apo-

\footnotetext{
gún evento específico relacionado con él; pero que, una vez decidida su inclusión, solo podía ser utilizado en ese lugar como epítome y generalización de cuanto ha dicho sobre Mónica en los libros precedentes de las Confesiones («Tears of Grief and Joy. Confessions Book 9: Chronological Sequence and Structure»: Augustinian Studies 28 (1997) 141-154: 148-151). Estamos de acuerdo en que esa breve biografía podía faltar sin que el conjunto de la obra sufriese y en que, en todo caso, está ubicada en el único lugar adecuado, pero no por su condición de epítome y generalización de lo dicho anteriormente -puesto que nada de lo aquí reseñado ha aparecido previamente, al menos de forma explícita-, sino como complemento, esto es, para así ofrecer una visión global de la figura de Mónica que incluyese también su relación con las demás personas de su entorno inmediato, no solo con Agustín.

${ }^{72}$ Solo que, como en la primera parte del relato aparecía Patricio en el rol de actor secundario al lado de Mónica, ahora, al término del mismo, aparecen Adeodato y Navigio -el hijo y el hermano- con el mismo rol, al lado de Agustín.

${ }^{73}$ Años atrás la escena fue objeto de un intenso debate entre los estudiosos. Lo que se discutía era si se trataba de una experiencia de cuño fundamentalmente neoplatónico o cristiano y, en este último caso, si se podía hablar de experiencia mística en sentido propio o no. Una breve síntesis en J. K. COYLE, «In Praise of Monica: A Note on the Ostia Experience of Confessions IX»: Augustinian Studies 13 (1982) 87-96. Nuestra perspectiva es distinta.
} 
yados en el alféizar de la ventana de la casa que habitaban, cual si fuera la misma regla de fe. Mónica ya no ve a Agustín como fuente -indirecta al menos- de su felicidad sino como compañero sediento que anhela beber junto a ella de la misma Fuente divina. La suma dulzura que acompaña su conversación es prueba de que habían quedado atrás unas relaciones marcadas por múltiples discrepancias, al menos desde la perspectiva de Agustín obispo: discrepancia sobre las motivaciones de la instrucción escolar, discrepancia a propósito de la recepción del bautismo, discrepancia en relación con la castidad, discrepancia sobre la conveniencia o no de un matrimonio temprano; discrepancia sobre la interpretación de un sueño, discrepancia sobre la conveniencia de partir para Italia; diferencia en la relación con Ambrosio -cálida en el caso de Mónica, fría en el caso de Agustín-. Cierto que una conversación dulce no presupone necesariamente el acuerdo $(6,23)$, pero sí que sea el tono general $(4,13)$. Dada la condición social del hombre, una conversión no puede no manifestarse en un nuevo modo de relacionarse sobre todo con aquellas personas con las que la relación no había sido la deseada. En definitiva, Mónica y Agustín, que tiempo atrás habían caminado por la misma calzada pero por distintos carriles, avanzaban ya juntos por el mismo carril, una vez que el hijo se había pasado definitivamente al carril religioso de la madre y la madre había dejado de invadir el carril mundano del hijo que él mismo acababa de abandonar.

El carril es una vía que conduce a una meta y un carril único conduce a una única meta. Esa única meta la revela el tema de la conversación entre ambos, madre e hijo: la Vida eterna, idéntica al Ser mismo, a la Verdad indeficiente, a la Sabiduría creadora, origen de todo, pero ajena al tiempo. Agustín, que había presentado la conversión de Mónica en Milán como una inundación de gozo, alternativa al duelo causado por dos muertes, muestra el deleite y el gozo (delectatio, iucunditas) como motor del proceso de ascenso en búsqueda de lo que anhelan. Los descartes no los hacen según criterios de bondad o maldad -pues toda criatura es buena, sino según criterios de mayor o menor deleite o gozo. ¿Cómo quedarse con lo que ni siquiera admite comparación con la Vida, o el Ser, o la Verdad, o la Sabiduría? Pero a ese criterio subyace otro, igualmente en grado comparativo, el de un amor más ardiente (ardentiore affectu). También aquí, como Agustín indica más adelante en las mismas Confesiones $(13,10)$, es el amor el que mueve todo y marca la dirección del movimiento, en este caso, de la búsqueda. La autenticidad de ese amor la 
prueba el haber llegado a tocar «con todo el ímpetu de su corazón» el objeto perseguido, objeto que no se dona sino al amor, don de quien se deja encontrar. El contacto, efímero, cumplió una doble función: ofrecer una breve experiencia fruitiva y avivar aún más el deseo de otra más intensa y duradera, de beber a morro directamente en los chorros de la Fuente divina, en vez del tenue refresco de una simple salpicadura (9,23-24).

El «éxtasis de Ostia» justifica la pregunta que formula Mónica ya al final del relato: «¿Qué hago yo ya aquí?». El fundamento de la misma es el deleite: "Ya nada me deleita en esta vida», y el fundamento de este, el precedente contacto, aunque efímero, con la Vida. Detrás de su conversión estaba una muerte, con el consiguiente luto, transformado en gozo que solo podía ser de vida. El mundo con todos sus deleites ha perdido todo su valor (vilesceret cum omnibus delectationibus suis) $(9,26)$ al lado de otro gozo de valor infinitamente mayor (carius: 8,30).

$\mathrm{El}$ «éxtasis de Ostia» es historia -no hay razones para negarlo- y recapitulación, no de cosas ya dichas sino de lo que, en opinión de Agustín, implica una conversión auténtica ${ }^{74}$. Si la conversión es un «volverse a», la conversión auténtica, o plena, es aquella que solo tiene ojos para el «objeto» hacia el que se ha vuelto, sin que nada los aparte de él.

\section{b) Verificación de la conversión moral}

Si una persona convertida solo tiene un único objeto en el que centrar su atención, trasciende cualquier otro objeto posible. Desde esta perspectiva -dejando de lado su inspiración neoplatónica- cobra todo su significado el proceso ascensional del relato agustiniano. En el caso concreto, trascender significa descartar, pero no porque se trate de realidades mo-

${ }^{74}$ La visión de Ostia -escribe M. Djuth- representa la culminación no solo de la conversión de Agustín al cristianismo, sino también la de Mónica («Augustine, Monica and the love of wisdom», p. 251). En primer lugar sería más apropiado cambiar el orden de los sujetos, puesto que el relato sobre Agustín se integra en el relato sobre su madre. Es la visión de Mónica, acompañada por Agustín, no al revés. En el fondo así lo reconoce la autora cuando escribe que la unidad de la ascensión contemplativa a Dios refleja el retorno del hijo pródigo a su padres, pero ahora mediante la mediación de su madre (cursiva nuestra) que funge de recuerdo de la Iglesia (ibídem). Por otra parte, hay que entenderla como culminación solo en cuanto verificación de que la conversión había sido una realidad, no en el sentido de que previamente no había sido completa. 
ralmente inaceptables, sino porque no aportan el nivel de deleite y gozo, capaz de saciar la sed del convertido. De hecho, el primer descarte recae sobre el mundo sensible -creación física- y el segundo sobre las propias almas -creación espiritual- $(9,24)$, En cuanto creación de Dios, una y otra son buenas, pero ofrecen sólo gotas de rocío a quien aspira a beber directamente de la Fuente. Eso en el mejor de los casos; en el peor, apartan del objetivo último cuando se presentan como alternativa a él, en la forma de apetencia de bienes materiales, o de orgullo y vanidad.

Desde esta perspectiva se entienden dos datos que Agustín aporta sobre Mónica ya convertida. Ambos, relacionados entre sí, muestran cómo el espacio que hasta su conversión habían ocupado apetencias mundanas lo ocupaban ahora consideraciones más elevadas. Como ejemplo concreto de la renuncia de Mónica a sus antiguas ambiciones, Agustín aduce el cambio experimentado en relación a su sepulcro y a su sepultura. En cuanto al primero, señala que, aunque ya había adquirido y preparado uno en su tierra natal, junto al cuerpo de su marido, cuando se acercaba el momento de su muerte manifestó no importarle el lugar, sabedora de que Dios está en todas partes. El cambio extrañó a su hijo, que recordaba que esa constante preocupación la tenía atenazada $(9,28)^{75}$. Agustín ya obispo califica esa antigua preocupación de pura vanidad (inanitas), añadiendo que ignora cuándo comenzó a desaparecer de su interior ( $i b$.). Pero es lógico suponer que formaba parte de la renuncia a disfrutar de los nietos que esperaba de su hijo, que conllevaba el desapego de otras «vanidades» ${ }^{76}$.

Más llamativo resulta el desapego de toda vanidad en relación ahora, no al lugar, sino al modo de su sepultura. Escribe Agustín: «Estando in-

${ }^{75}$ Un «desprendimiento espiritual impresionante», según P. Langa («Santa Mónica y su mensaje hoy», en (V. D. CANET (ed.), San Augustín: 1650 aniversario de su nacimiento (Jornadas Agustinianas 7, Madrid 2004) 51-75:65).

${ }^{76}$ C. Alonso del Real lo relaciona con la visión de Ostia, al término de la cual Mónica se pregunta qué hace ya en esta tierra $(9,26)$. La autora se apoya en que antes de manifestar esa indiferencia respecto al lugar de su sepultura, el grupo de amigos que volvían a África habían hablado del desprecio de esta vida y del bien de la muerte, causando Mónica estupor entre los asistentes por su fortaleza de mujer $(9,28)$ («Monnichae laudatio», en I. P. AugusTinianum (ed.), Le Confessioni di Agostino (402-2002), p. 241. Pero parece más correcto pensar que la escena tuvo lugar ya antes de la visión de Ostia, pues la indicación «cuando ya estábamos en Ostia» (cum Ostiis essemus) sería innecesaria, dado que la visión había sido ubicada en tal lugar. 
minente el día de su liberación, no pensó en que su cuerpo recibiera sepultura con gran pompa o en que fuera embalsamado con aromas, ni deseó un monumento escogido, ni se preocupó de ser sepultada en su patria» $(9,36)$. La simple mención de estas renuncias es confesión de antiguos apegos. Ciertamente es Agustín quien lo afirma, no Mónica, pero no procede dudar de que refleja sueños de la madre. En todo caso, es difícil evitar la pregunta de si los medios económicos de que disponía Mónica le permitían imaginar para sí un funeral como el descrito, propio de las clases pudientes. No es de excluir, pues, que hubiese esperado usufructuar el fantaseado éxito de su hijo por el que había luchado. Desprenderse del sueño se lo impuso la realidad, pero aceptarlo fue don de Dios, que convirtió su frustración en gozo $(8,30)$. A partir de entonces solo le importaba que Dios se acordase de ella. Dejó de apetecer que los hombres la recordasen como la madre del triunfador Agustín; de ellos solo quería el recuerdo ante Dios: «Solo nos expresó que nos acordáramos de ella ante tu altar, a cuyo servicio había estado ininterrumpidamente, sin dejar ni un solo día» (ib.).

No solo se habían diluido viejas ambiciones; también habían desaparecido actitudes no particularmente elogiables. Por ejemplo, si a lo largo de los primeros ocho libros de las Confesiones Agustín ha mostrado a su madre como obsesionada exclusivamente con él, ahora la presenta como madre e hija del grupo que lo acompañaba. Mónica aceptó la maternidad espiritual respecto de todos. Los lazos «privados» de la carne cedieron ante los lazos «comunes» del espíritu ${ }^{77}$; el afán por imponer su voluntad cedió su lugar a la disponibilidad para servir a todos: «Cuidó de cuantos vivíamos unidos en ti después de recibir la gracia del bautismo y lo hizo como si nos hubiera dado a luz a todos. Y se puso a nuestra disposición como si fuera hija de todos» $(9,37)^{78}$.

En definitiva, el relato recapitula y concentra en un momento lo que ya había tenido lugar previamente: el trascender otros «objetos» distintos de Dios había comenzado antes del «éxtasis de Ostia».

77 Dejó de ser «mi madre» o «la madre de mi carne» (conf.1,17) respecto de Agustín, para pasar a ser «nuestra madre», respecto del grupo de Casiciaco (beata u. 6; ord. 1,22).

${ }^{78}$ Esta nueva conciencia se trasluce también en la súplica de su hijo al término del libro noveno de las Confesiones: «Acuérdense con sentimientos de afecto de quienes fueron mis padres en esta luz pasajera, y hermanos míos que le tienen como Padre en el seno de la madre católica, conciudadanos míos en la Jerusalén eterna» $(9,37)$. 


\section{Extrayendo conclusiones}

Comenzamos distinguiendo dos niveles de santidad: la «común»- la que posee todo bautizado que no ha perdido la gracia- y la «clarior» -la del fiel que ha alcanzado tal nivel de perfección en las virtudes teologales, cardinales y anejas que justifica que se la proponga de manera oficial como modelo para el conjunto de la Iglesia ${ }^{79}$. Por supuesto, referida a la época de Agustín, se trata de una división anacrónica, pues se ubica en el contexto -desconocido en la Iglesia antigua- de las «canonizaciones»o declaraciones oficiales de santidad. No obstante, el contexto señalado al inicio de este trabajo -la inclusión o no en el santoral universal de la Iglesia- justifica utilizarla aquí.

Agustín considera santa a Mónica, incluso antes de la conversión, en cuanto miembro de la comunidad de bautizados $(8,5)$. Es un dato obvio, pues nunca se vio sometida a la penitencia pública, ni abandonó la Iglesia, en la que participaba a diario de la Eucaristía $(9,36)$ y en cuyo seno murió $(9,28)$. Si se piensa en la santidad «común» no hay problema en aceptarla.

¿Qué decir de la santidad «clarior»? Las páginas de las Confesiones ofrecen algunos datos, útiles al respecto. A nivel terminológico, Agustín nunca aplica a su madre, a título individual, el calificativo de santa, como lo aplica, por ejemplo, al obispo Ambrosio $(9,13 ; 6,4)$. En cambio, en el libro noveno -solo en él- juzga santa su vida $(9,22.33)$. Pero aunque siempre es útil tener en cuenta la terminología, no basta para determinar la santidad que implica, siempre y simultáneamente, una muerte y una vida: muerte al pecado y vida en Dios. De la muerte al pecado por parte de Mónica habla Agustín en el último capítulo del libro noveno (\$\$34-37), en el que hace una triple declaración en relación con la condición pecadora de su madre, mostrando una notable reticencia a declarar que lo fue. En la primera, remitiendo a Mt 5,22, no se atreve a afirmar que ella no hubiese faltado de palabra después de bautizada $(9,34$; cf. 5,15$)$; en la segunda, ya sin restringirse a los pecados de la lengua, pide perdón por las deudas de su madre, «si es que contrajo algunas durante tantos años después de bau-

${ }^{79}$ Sanctitas clarior es el título de la carta apostólica de Pablo VI, del 19 de marzo de 1969, en la que modificaba el proceso que debía seguirse en las causas de beatificación y canonización de los santos. 
tizada» (9,35); en la tercera, declara que ella no diría que no tuvo deudas, no fuera que la dejase convicta de lo contrario el astuto acusador; diría más bien que le fueron perdonadas por Cristo $(9,36)$. Las tres declaraciones muestran la dificultad que tiene Agustín para combinar su teología y la imagen final que quiere dar de Mónica. De una parte quiere presentarla como libre de pecado después del bautismo; de otra, no puede negar que fue pecadora, pues, entre otras razones, eso equivaldría a declarar innecesario el rezo del Padrenuestro (cf. Mt 6,12). La solución que encuentra es dejar a la madre el «merito» de reconocer su pecado y personalmente no pronunciarse claramente al respecto - «no me atrevo», «sí...»-. En realidad no resuelve el problema y, además, se traiciona a sí mismo al suplicar encarecidamente a sus lectores que ante el altar oren al Señor por su madre $(9,27.37)$. Las dudas señaladas aparecen aquí como certezas, que quizá tenían que ver sobre todo con lo que había escrito en los primeros libros de la obra, aunque referido a la etapa previa a la conversión.

Pero la santidad no es solo muerte al pecado; es también nueva vida en Dios, decíamos. Con su conversión Mónica comenzó una nueva vida espiritual que tenía a Dios como centro único. Agustín describe la vida nueva de Mónica como gozo en Dios porque había muerto el «hijo muerto» $(6,1)$ y en sustitución del dolor que le produjo ver frustradas de sus propias esperanzas mundanas. Según esto, no cabría hablar de santidad de Mónica -por supuesto, de la santidad «clarior»- más que a partir del libro noveno de las Confesiones, pues hasta entonces su gozo, al menos parcialmente, se había sustentado en ambiciones o simples deseos, es decir, a lo más en esperanza de gozo, no en gozo ${ }^{80}$. Ese gozo alcanzó su cima más alta en la experiencia de Ostia, compartida con el hijo, efímera en verdad, pero capaz de encender el deseo de experimentarlo en su plenitud indeficiente (9,23-25).

${ }^{80}$ De hecho, leyendo entre líneas, las páginas agustinianas parecen presentar a Mónica como una mujer ávida de promoción social e, indirectamente, de poder económico. Al no poder conseguir personalmente ni lo uno ni lo otro, proyectó su ambición en el éxito del hijo. Por otra parte, y sin entrar en otro tipo de consideraciones, se la podría acusar de cierta esquizofrenia: impacientada en relación con la fe católica de su hijo, relajada en cuanto a la moral, pues, de un lado, recomienda al hijo vivir conforme a las exigencias cristianas; de otro, las aparca si juzga que son un obstáculo para el logro de las ambiciones tanto del hijo como propias. Se la podría comparar con personas intransigentes ante ciertos valores religiosos, pero liberales ante otros, en función de los propios intereses. 
La presentación hecha pudiera dar la impresión de que entre la santidad «común» y la santidad «clarior» se ha producido una especie de rotura; que la conversión significó el paso sin más de una a otra. Pero más que de rotura procede hablar de transición, en la que lo nuevo ya tenía sus raíces en lo viejo y lo viejo mantuvo las suyas, debilitadas sin duda, en lo nuevo. Toda vida cristiana se sostiene en la fuerza creadora de la gracia de Dios, y en toda vida cristiana se manifiesta la fuerza destructiva del pecado. Que se pueda hablar de santidad «común» o de santidad «clarior» depende de la correlación de ambas fuerzas. El paso de una a otra es progresivo y está marcado por el imponerse de la gracia sobre el pecado. Agustín construye el relato sobre su madre mostrando en ella tanto la fuerza de la gracia en su acompañamiento del hijo hacia el bautismo, como la fuerza del pecado, en su acompañamiento hacia el éxito social. La victoria de la gracia se manifestó en que el primero recorrido llegó a su término, y el segundo no. Y con esta victoria, aún inicial, comienza a manifestarse la santidad «clarior», que se hará más «clarior» a medida que se vaya confirmando la victoria en su doble aspecto de cerrar la puerta a la muerte que se goza en el pecado y abrirla a la vida que se goza solo en Dios. Una santidad que en esta vida puede ser cada vez «clarior»-más resplandeciente-, pero nunca llegaraa ser «clarissima», es decir, nunca podrá alcanzar la plenitud porque la fuerza del pecado, por disminuida que esté, sigue estando presente. La prueba son las «dudas» de Agustín sobre el pecado de su madre y la súplica de oraciones por ella. La santidad plena solo pertenece a Dios; el hombre participa de ella en distintos niveles, que se miden por el grado de amor. La santidad es vida en Dios y, como toda vida, también ella nace, se desarrolla y alcanza su específico nivel de perfección en el curso del tiempo, mayor o menor según personas y, en última instancia, según el don de Dios. Unas veces el desarrollo es continuo a partir del bautismo, y otras con cierto grado de discontinuidad, mediando una conversión. Es el caso que Agustín contempla en su madre. En su caso, no cabe pensar que llevase su carro de «compra» de productos de santidad totalmente vacío y que solo comenzara a adquirirlos en el momento de la conversión, no; lo que hizo entonces fue descubrir que había adquirido también productos adulterados, desprenderse de ellos y sustituirlos por otros auténticos. Pero eso no significa que no quedase en el carro algún producto adulterado, ni que consiguiese llenarlo hasta el tope. 
Varios autores han sostenido que, en las Confesiones, Agustín presenta a Mónica como figura de la Iglesia o, más en concreto, de la Iglesia en cuanto madre ${ }^{81}$. Si esto es así, no cabe sino concluir que él vio encarnada en su madre la santidad de la Iglesia. Mas para que la afirmación sea verdad plena, hay que tomar en consideración otro estudio que ofrece el matiz importante de presentar a Mónica como imagen de la Iglesia peregrina y, a la vez, como miembro de ella en proceso de transformación. Se trata de dos aspectos de su figura -personificación de la Iglesia e individualidad demasiado humana- que han de ser integrados, no meramente yuxtapuestos. De hecho, las imperfecciones de Mónica -el autor señala lo referente al bautismo del hijo enfermo, a sus estudios, a un matrimonio socialmente ventajoso- tal como las relata Agustín son parte integrante de lo que él quiere decirnos sobre la Iglesia y sobre la vida cristiana de sus miembros ${ }^{82}$. En breve, como la Iglesia peregrina es imperfecta y pecadora, a pesar de ser santa, también se puede considerar santa a Mónica, a pesar de que tampoco ella logró desprenderse enteramente de su pecado e imperfecciones.

La figura de Mónica que presentan varios estudiosos, como ya indicamos al comienzo, resulta poco luminosa. Quitan brillo a su figura al poner de relieve en ella cualidades y actitudes poco ejemplares; al sugerir la posibilidad de que Agustín haya coloreado los aspectos menos positivos de la figura de Mónica como consecuencia de los sentimientos negativos de él hacia su padre ${ }^{83}$; o al indicar que Mónica, que había sido idealizada en la primera parte de la obra -considerada previamente como un oráculo de Dios-, al término del libro noveno de las Confesiones Agustín la reduce a un ser humano ordinario, objeto de preocupación, pecadora como él y

${ }^{81}$ Cf., por ejemplo, las siguientes autoras: L. SEelbach, «Agustín y Mónica... », p. 26; K. Power, Veiled desire, p. 83; A. Benvenuti, «Conclusioni», en M. Chiabò - M. Gargano - R. RonZani (ed.), Santa Monica nell'Urbe, p. 278;M. DulaEy, «Scatentes lacrimis...», p. 218-219.

82 J. SeHORN, «Monica as Synecdoche...», 232-233. A. Pic, por su parte, ve en Mónicauna «figura del sensus fidelium» («Sainte Monique come figure du sensus fidelium. Rapide lecture de quelques passages des Confessions», en M. L. CHAIEB (ed.), Les Pères de l'Église à l'écoute du peuple de Dieu. Sensus fidelium et discours autorisés durant l'antiquité tardive. Actes du VII colloque de la Rochelle (9,10 et 11 octobre 2015 (Caritas Patrum, Royan 2016), p. 195-209).

${ }^{83}$ K. POWER, Veiled desire, p. 80. 
como él igualmente necesitada de misericordia ${ }^{84}$. En este último caso, se puede dar la razón al erudito cuando afirma que, al final, Agustín convierte a su madre en un fiel cristiano de tantos. En efecto, a las puertas de la muerte, ante Dios nadie tiene otro motivo de confianza que su misericordia. En cambio, nos parece totalmente desacertado presentar a Mónica como una figura idealizada por su hijo ${ }^{85}$. Hay que distinguir entre el afecto agradecido desde el que Agustín escribe, tratando de comprender o, incluso, disculpar a su madre, y lo que escribe, pues ni la piedad filial le impidió verter críticas, algunas explícitas y no leves, hacia su madre. Lo cierto es que supo recubrirlas con tanta piedad filial que el lector no suficientemente atento no siempre advierte lo que tapa esa piedad ${ }^{86}$. Una cosa es reconocer, como hace Agustín, que Dios depositó múltiples dones en ella y considerarla como el instrumento de que se sirvió para devolverlo a la fe de la Iglesia, y otra cosa considerar que la idealizó. A lo más, podría discutirse si cuadra con el libro noveno tal afirmación, que ciertamente no cuadra con los ocho primeros, como hemos mostrado previamente. Asimismo, por mucho que se suavice hablando solo de posibilidad, sostener que Agustín haya expresado sus sentimientos negativos hacia su padre coloreando en positivo la figura de su madre, es un a priori, que necesita de-

${ }^{84}$ P. Brown, Augustine of Hippo. A Biography. New edition, with an epilogue (University of California Press, Berkeley y Los Ángeles 200), p. 157-158.

${ }^{85}$ Cf. J. Sehorn, «Monica as Synecdoche..., p. 233.

${ }^{86}$ En los primeros libros Agustín alude repetidas veces a la pietas de su madre: refiere que solicitó de la «piedad» de su madre el bautismo $(1,17 ; 5,16)$; menciona el derecho de la «piedad» materna $(1,17)$; califica como fuerte a su madre por su «piedad» $(6,1)$; habla asimismo de una sacudida «piadosa» de su madre $(2,6)$; del gozo de la mujer «piadosa» tras un sueño $(3,20)$. En tales textos no cabe pensar en la «piedad» como virtud específicamente religiosa, sino como la virtud doméstica, que regula la debida relación entre padres e hijos. La «piedad» de la madre es su amor por el hijo; una madre «piadosa» es una madre amorosa. Al emplear ese término, Agustín parece estar devolviendo a Mónica el cumplido. Basta advertir que durante la última enfermedad de la madre, él había recibido el consuelo de oírla decir-como queriendo pagarle con una caricia las atenciones que de él había recibido-que había sido un «buen» (pium) hijo, repitiéndole con gran afecto de cariño que nunca había oído salir de su boca una palabra áspera o hiriente hacia ella $(9,30)$. Como la madre reconoce la «piedad» del hijo para con ella, el hijo reconoce, multiplicada, la de la madre para con él. Por tanto, el niño Agustín confía en el amor materno para solicitarle el bautismo; el derecho de la piedad materna es el derecho del amor materno; la sacudida interior que sufre Mónica ante la información de Patricio sobre su hijo es de la Mónica madre; el gozo de la mujer piadosa es el gozo de la madre a la que se anuncia el regreso de su hijo a la fe. 
mostración, pues él no ha tenido dificultad en criticarla ${ }^{87}$. Por último, sin negar que Mónica tuvo sus deficiencias, procede considerar que la virtud y el vicio están a veces tan cercanos que la denominación de una acción puede caer de una parte o de otra -por ejemplo, tenacidad u obstinaciónsegún criterios puramente subjetivos.

Después de lo dicho, y para concluir, cabe formular la pregunta de si las generaciones y siglos posteriores, ávidos lectores de las Confesiones, aceptaron a la madre de Agustín cómo modelo de santidad que imitar. La respuesta no es muy halagüeña, pues Mónica resulta una figura singularmente ausente en el imaginario religioso femenino de la Edad Media ${ }^{88}$. En principio tenía todas las cartas para ser popular, al haber labrado su santidad específicamente en su condición de esposa y, sobre todo, de madre. Solo que hijos como Agustín no era fácil que se dieran en los siglos posteriores. A medida que la fe cristiana pasó a dominar la sociedad entera, si no los «Patricios», sí los «Agustines» eran personajes al menos en peligro de extinción, por lo que difícilmente había espacio para otras madres «Mónicas». La nueva situación religiosa general reclamaba otros tipos de santidad que marcasen la diferencia saliéndose de lo normal. Y normal se consideraba que una madre entregase su vida al servicio, por supuesto también religioso, de sus hijos. Para que cuajara el culto a Mónica tuvieron que darse nuevas condiciones culturales y espirituales, lo que aconteció con la aparición del humanismo cristiano que contemplaba a la persona en su dimensión natural e histórica, en el s. XV ${ }^{89}$. A partir de entonces, se percibe una verdadera explosión de devoción hacia la santa - una de cuyas manifestaciones fue el multiplicarse de su iconografía- en ciudades como Florencia, Bolonia y Venecia -además de Roma-, en las que los religiosos de la Orden de Ermitaños de San Agustín tuvieron un específico peso cultural ${ }^{90}$.

${ }^{87}$ Por ejemplo, si quería «penalizar» a su padre, podía haberle responsabilizado solo a él de haber antepuesto los intereses académicos a los morales $(2,8)$ y, sin embargo, carga la responsabilidad también sobre la madre.

${ }^{88}$ Cf. A. Bartolomei Romagnoli, «Madri sante nella letteratura medioevale», en M. Chiabò - M. GARgAno - R. RonZAni (ed.), Santa Monica nell'Urbe , p. 53-111: 111.

${ }^{89}$ Iв. La autora remite a P. PIATTI, «Il risveglio quattrocentesco di Santa Monica fra Umanessimo Medievale e “consorores” romanae»: Hagiografica 16 (2009) 281-316).

${ }^{90}$ Cf. A. Benvenuti, «Conclusioni», en M. Chiabò - M. GARgano - R. Ronzani (ed.), Santa Monica nell'Urbe, p. 280. 
Meses después de la muerte de Mónica, Agustín y los que le acompañaban se hicieron a la mar rumbo a la patria africana. De haber vuelto a Italia, Agustín habría desembarcado de nuevo en Ostia Antica y habría podido visitar la tumba de su madre. Pero el respeto que le imponía la mar, entre otras causas, se lo impidió. Atento al deseo que ella manifestó a las puertas de la muerte $(9,36)$, no le levantó ningún mausoleo. Para perpetuar su memoria, lo que hizo fue escribir sus Confesiones que no tienen nada que ver con un mausoleo. En efecto, mientras los mausoleos son morada para los muertos, en las Confesiones encontramos vivos al hijo, por supuesto, pero también a la madre con su amor materno -quizá descompensado- con sus defectos y sus virtudes; con el don de su santidad y el peso de su pecado; la Mónica real que se marcó un objetivo primordial en su vida y no paró hasta lograrlo, escribiendo, a veces, renglones torcidos; o al menos, la Mónica que recordó Agustín ya obispo. Y se puede añadir todavía: la madre que se levantó a sí misma un grandioso monumento que no es otro que su hijo Agustín ${ }^{91}$.

${ }^{91}$ La idea es de P. E. Mundig, según el cual, el hijo genial construyó a su madre un digno e imperecedero mausoleo, pero la madre se construyó a sí misma otro aún más señorial, su mismo hijo («Monnika und Augustinus. Ein heiliger Sohn über seine heilige Mutter»: Benediktinische Monatschrift 6 [1930] 261-269:269). El dato lo tomamos de L. Seelbach («"Wie sollte ich selbst...»,p. 318). 